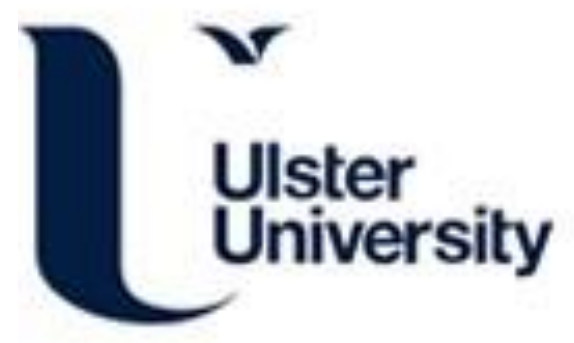

\title{
Holocene evolution of the Xagó dune field (Asturias, NW Spain) reconstructed by means of morphological mapping and ground penetrating radar surveys
}

Flor-Blanco, G., Rubio-Melendi, D., Flor, G., Fernández-Álvarez, J. P., \& Jackson, D. W. T. (Accepted/ln press). Holocene evolution of the Xagó dune field (Asturias, NW Spain) reconstructed by means of morphological mapping and ground penetrating radar surveys. Geo-Marine Letters, 36((1)), 35-50. https://doi.org/10.1007/s00367-015-0427-1

Link to publication record in Ulster University Research Portal

Published in:

Geo-Marine Letters

Publication Status:

Accepted/In press: 06/01/2016

DOI:

10.1007/s00367-015-0427-1

Document Version

Publisher's PDF, also known as Version of record

\section{General rights}

Copyright for the publications made accessible via Ulster University's Research Portal is retained by the author(s) and / or other copyright owners and it is a condition of accessing these publications that users recognise and abide by the legal requirements associated with these rights.

\section{Take down policy}

The Research Portal is Ulster University's institutional repository that provides access to Ulster's research outputs. Every effort has been made to ensure that content in the Research Portal does not infringe any person's rights, or applicable UK laws. If you discover content in the Research Portal that you believe breaches copyright or violates any law, please contact pure-support@ulster.ac.uk. 


\title{
Holocene evolution of the Xagó dune field (Asturias, NW Spain) reconstructed by means of morphological mapping and ground penetrating radar surveys
}

\author{
G. Flor-Blanco $^{1}$ • D. Rubio-Melendi ${ }^{2}$ • G. Flor ${ }^{1}$ • J. P. Fernández-Álvarez ${ }^{2}$. \\ D. W. T. Jackson ${ }^{3}$
}

Received: 17 July 2015 / Accepted: 6 October 2015 / Published online: 27 October 2015

(C) Springer-Verlag Berlin Heidelberg 2015

\begin{abstract}
Morphological mapping and ground penetrating radar (GPR) profiling were carried out in the Xagó aeolian dune field along the Asturias coast of NW Spain to reconstruct its Holocene evolution. Such data provide a much more accurate picture than can be inferred from surficial morphological studies alone. Three successive dune sequences were identified: an inner (climbing dunes), a middle (large transverse ridge and minor elongated dunes) and an outer dune field (foredune with lee-projection dunes and incipient foredune). A late Holocene sea-level fall is inferred from the relative position of the dunes together with a prograding tendency. Long intervals of stabilisation, during which each dune sequence was formed, are interspersed within the deposit. The GPR records also reveal a period of erosion in the southern middle field, which was followed by accretion. The results show that both progradational and erosional processes occurred during the Holocene evolution of the dune field, features that can be extended to other dune fields in similar settings at these latitudes. Stratigraphically, the Xagó dune field is an excellent example where internal reflectors reveal an erosion surface representing a transgressive or sea-level stillstand event that had previously remained undetected.
\end{abstract}

G. Flor-Blanco

gfb@geol.uniovi.es

1 Department of Geology, GeoQUO Research Group, University of Oviedo, Arias de Velasco, s/n, 33005 Oviedo, Asturias, Spain

2 Hydro-Geophysics and NDT Modelling Unit, Polytechnical School of Mieres, University of Oviedo, c/ Gonzalo Gutiérrez Quirós, s/n, 33600 Mieres, Asturias, Spain

3 School of Environmental Sciences, Ulster University, Cromore Road, Coleraine BT52 1SA, Northern Ireland, UK

\section{Introduction}

Sea-level records along the northern coastline of Spain have suffered from a general paucity of good datable material, particularly in terms of Pleistocene deposits that are poorly preserved in the current environmental settings. However, four pronounced marine terraces of early to mid-Pleistocene age occur at elevations between 5 and $60 \mathrm{~m}$ in the central part of Asturias (Hoyos 1989). Furthermore, along the Cantabrian coast, a continuous raised beach deposit from the last interglacial period has been identified by Martínez Graña et al. (2000) and Alonso and Pagés (2007). Coastal deposits from the last glacial to Holocene period have received most attention and involve sediments found in solifluction, colluvial, beach and dune environments. Infrequent peat horizons, together with beach and aeolian dune deposits, provide the best evidence of interglacial periods along the eastern Cantabrian coastline. Leorri et al. (2012) conclude that the sea level rose slowly from $7 \mathrm{ka}$ onwards, and that sand bars developed in the mouths of the northern estuaries from 5-4 ka (Cearreta et al. 2007). Between 4 and $2 \mathrm{ka}$ the sea level fell, followed by a rise of 0.7 to $0.3 \mathrm{~mm}_{\text {year }}{ }^{-1}$ during the pre-anthropogenic period (Leorri et al. 2012). At present, based on coastal tide gauge records and dating of marsh cores, the sea-level rise in the Bay of Biscay is about $2.08 \pm 0.33 \mathrm{~mm}_{\text {year }}{ }^{-1}$ (Chust et al. 2009), corresponding rates during the 20th Century amounting to about $1.7 \pm 0.2 \mathrm{~mm}_{\text {year }}{ }^{-1}$ (García-Artola et al. 2015).

Elevated outcrops of Holocene gravelly and/or sandy beach deposits locally overlie other continental sediments (Flor and Flor-Blanco 2014) of early Flandrian age. Most of these occur more than 5-7 $\mathrm{m}$ above the modern sea level at various locations in NW Spain, such as Gallín (east of Galicia), dated at 5,580-5,530 years BP (Feal-Pérez et al. 2009; Feal-Pérez

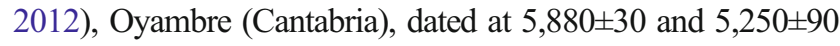
years BP (Mary 1983), and the Gorliz dunes (Biscay), dated at 
5,710 \pm 50 years BP (Cearreta et al. 1990). According to Edeso (1994), the late Flandrian landward limit of transgressive deposition occurred after 4,920 \pm 100 years BP.

Along the Cantabrian coast, however, only a few records of prograding dune systems date after the maximum Flandrian transgression. In addition, previous studies on the Holocene of the Cantabrian coast in western Spain (Feal-Pérez et al. 2014) and along the coast of Asturias (Flor and Lharti 2008) complement the present study. Comparisons were also made with outcrops found on the Salinas beach/dune system (confining barrier) of the Avilés estuary, the characteristics and origin of which are similar to those of the Xagó dune field (Flor-Blanco et al. 2013). The Salinas beach and associated aeolian dunes have previously been studied from morphological and sedimentological perspectives by Flor $(1978,1981,1986)$ and Suárez Ruiz and Sánchez de la Torre (1983).

Prior to the availability of ground penetrating radar (GPR), the internal architecture of aeolian dune fields was reconstructed on the basis of characteristic surface and near-surface features (topography, morphology, texture and composition of sands, and sedimentary structures), involving trenching (e.g. Bigarella et al. 1969; Ruz and Allard 1995) and computer modelling (e.g. Rubin 1987). To reduce sediment disturbance, new trenching techniques have, amongst others, been developed (e.g. Araújo-Gomes and Ramos-Pereira 2015). With the advent of GPR and constantly evolving modelling capabilities, two- and three-dimensional images of undisturbed beach, dune and shoreface deposits can be generated, which greatly improve reconstructions of their development (e.g. Nielsen et al. 2009; Kim et al. 2013).

Initial applications of GPR in coastal environments date back to the 1980s (e.g. Ulriksen 1982; Leatherman 1987; Truman et al. 1988; for review, see Van Dam 2012). Those and later studies focused on the geometry of reflectors, corresponding radar facies and associated sedimentary sequences (e.g. Bristow et al. 2000; Neal 2004). Thus, several studies have demonstrated the effectiveness of applying GPR in coastal environments (see Buynevich et al. 2009), in particular coastal dune fields (see Bristow and Jol 2003; Bristow 2009), thereby identifying different phases of progradation and erosion (e.g. Tanner 1995; Bristow and Pucillo 2006). In fact, many coastal studies are predominantly based on this nondestructive method for interpreting sedimentation and sea-level changes. Good examples are available from North America (Fisher et al. 1995; Van Heteren et al. 1998; Buynevich and FitzGerald 2001; Havholm et al. 2004; Girardi and Davis 2010), Vietnam (Lee et al. 2013), India (Gujar et al. 2011), northern Europe (Bristow et al. 2000; Clemmensen et al. 2001; Nielsen et al. 2009), Australia (Harari 1996; Bristow et al. 1996, 2007; Bristow and Pucillo 2006) and New Zealand (Van Dam et al. 2003). In Portugal, the GPR method has experienced a remarkable expansion in recent years
(Moura et al. 2007; Ramos et al. 2010, 2011), while in Spain it has found wide application in the dunes of the Ebro Delta (Gómez-Ortiz et al. 2009; Rodríguez Santalla et al. 2009), and in Galicia on the Cíes Islands (Costas et al. 2006), at Traba (González-Villanueva et al. 2011a) and in the Corrubedo dune system (González-Villanueva et al. 2011b).

In this context, the purpose of the present study was to map the different surficial dune morphologies and apply GPR in the Xagó dune field of Asturias in NW Spain, to determine its internal architecture, identify features relating to sea-level oscillations and, together with age datings, reconstruct the Holocene evolution of the system. The non-destructive GPR method was of particular value because the beach/dune system of Xagó is a protected landscape designated in 2000 as an SCI (Site of Community Importance) and SZBP site (Special Zone of Bird Protection). A similar approach has proved very successful in, for example, reconstructing the Holocene evolution of the Nazaré coastal dunes in Portugal (Ramos et al. 2010).

\section{Regional setting}

Asturias is located on the Cantabrian coast (NW Iberian Peninsula) and is characterised by a tectonically stable rocky coast that forms part of the Cantabrian Range, which extends in a W-E direction (Fig. 1). The coastal temperatures are rarely below $0{ }^{\circ} \mathrm{C}$ or over $30^{\circ} \mathrm{C}$, summer coastal temperature averaging at $25^{\circ} \mathrm{C}$, and springs and autumns being mild due to the influence of the Atlantic. Based on AEMET (National Agency of Meteorology) data, the rainfall along the coast (1970-2009) varies from 800-1,200 mm year ${ }^{-1}$ (González Taboada and Anadón 2011).

The main ocean wave fronts approach from the NW (Iglesias and Carballo 2010) and refract onto the NE-SW oriented beach, making it one of the highest-energy beaches along the Cantabrian coast. Wave dynamics is very variable, ranging from low energy along the western part of the beach (shadow zone) to progressively higher energy towards the broad central and eastern beach sectors (exposed zone). Based on historical records from 1974-2012 (Asturias airport data), SW and WNW winds are dominant (23\%) but are not important in deflating sand from the beach to the dune field due to a back slope of more than $20 \mathrm{~m}$ that confines the beach. NW winds (8\%), however, are important in this aeolian process. During anticyclonic conditions, E and NE (17\%) winds are also strong enough to contribute to the total sand transport (Fig. 2). Typical wind speeds along this coast mostly vary up to $7 \mathrm{~m} \mathrm{~s}^{-1}$ but may exceed $11 \mathrm{~m} \mathrm{~s}^{-1}$ on rare occasions (http:// weatherspark.com/averages/32022/Aviles-Gijon-OviedoAsturias-Spain). Tides are semidiurnal and mesotidal with highest and lowest astronomical tides of $4.7 \mathrm{~m}$ and $0.2 \mathrm{~m}$ respectively, the mean tide level averaging at $2.47 \mathrm{~m}$ (data 

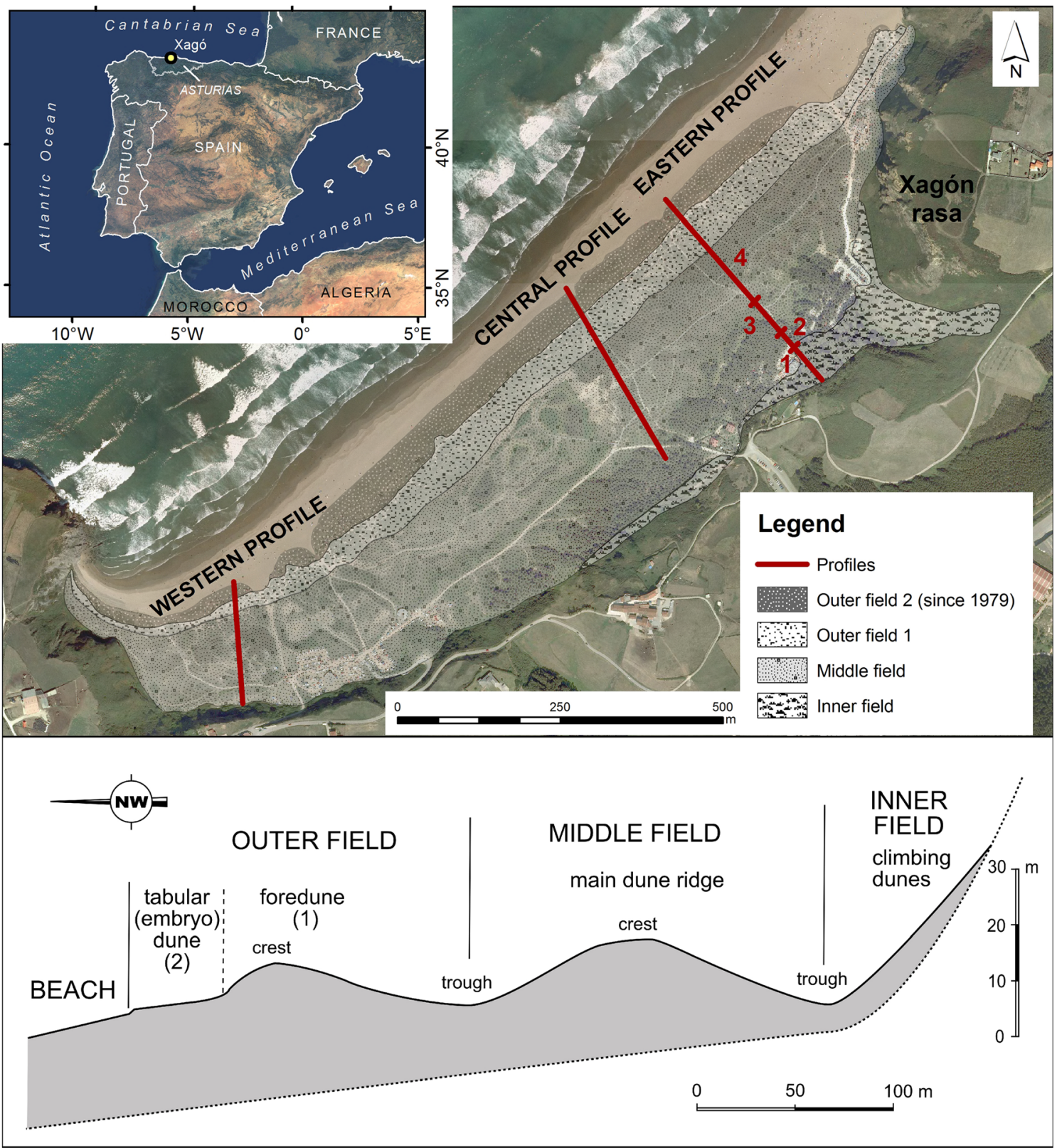

Fig. 1 Top Location of the Xagó beach/dune complex (central Asturian coast, NW Spain) with the different dune fields (red numbers different sections of eastern profile). Bottom Cross-section of the longest and most complete profile (eastern sector)

from the port of Gijon located $18 \mathrm{~km}$ to the SE; NGIA 2014). Morphodynamically, the beach is fully dissipative (Short 2006; Short and Jackson 2013).

The study area is confined by $40-100 \mathrm{~m}$ high cliffs, in some places topped by old irregularly staggered erosion surfaces called "rasas" (Flor and Flor-Blanco 2014). The upper rasa in this region is the Xagón surface (Fig. 3), preserved on an isolated hill carved into Palaeozoic sandstones. The base of the surface is located in the south at an elevation of $115 \mathrm{~m}$ (rasa VI). To the east (El Otero), an aeolian sand outcrop belonging to rasa VIII is preserved. Its nick point, which has been linked to a sandy beach, is located at an elevation of $65 \mathrm{~m}$
(Flor-Blanco et al. 2013). As the coast is bounded by steep slopes, the availability of sediments from rivers, which are the most important source, is very restricted.

From a morphological point of view, the beach planform is sub-rectangular and elongated, stretching for $1.8 \mathrm{~km}$ in a NESW direction. The backshore and foreshore are approx. $130 \mathrm{~m}$ wide, increasing to $175 \mathrm{~m}$ at the eastern end, where sand is retained by a headland. The width of the aeolian dune field progressively increases from $45 \mathrm{~m}$ in the west (due to the shadow effect of the headland during north-westerly winds) to a maximum width of $450 \mathrm{~m}$ at the eastern margin of the exposed beach, from where it rapidly narrows towards the 

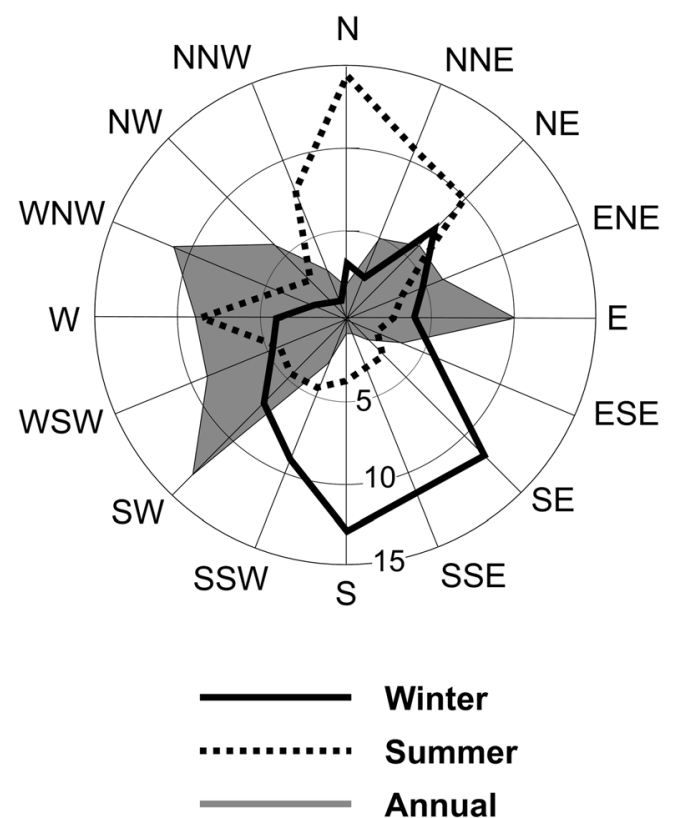

Fig. 2 Frequency (\%) of coastal winds during summer and winter (from Rasilla et al. 2004) based on daily records from November 2000 to September 2012 (http://es.windfinder.com/windstats/windstatistic_ asturias_aviles.htm) confining headland. The best preserved dunes are found in the central and eastern sectors of the exposed beach zone (Fig. 3). The beach sand is composed of fine siliciclastic sand supplied by the Nalón River and its tributary, the Narcea River, the mouth of which is located $14 \mathrm{~km}$ to the SW, as deduced from heavy mineral contents (Flor 1978) and the eastward directed littoral transport (Flor-Blanco et al. 2013). The average grain size of the intertidal beach sand is $2.12 \mathrm{phi}(0.23 \mathrm{~mm})$, whereas the dune sands are finer ( 2.33 phi or $0.20 \mathrm{~mm}$ ), the size decreasing landwards and from the SW to NE (Flor 1981).

From the 1950s to the 1980s, the dune field experienced heavy sand losses, particularly in the western half, because of sand mining activities. Since the 1990s, the dune field has been partially restored, but large artificial hollows have deliberately been retained and converted into permanent ponds fed from the very shallow water table. Other areas were converted into recreational and parking areas, access to the beach being controlled by numerous fixed footpaths and some wooden walkways. Small hollows were created as temporary landfills.

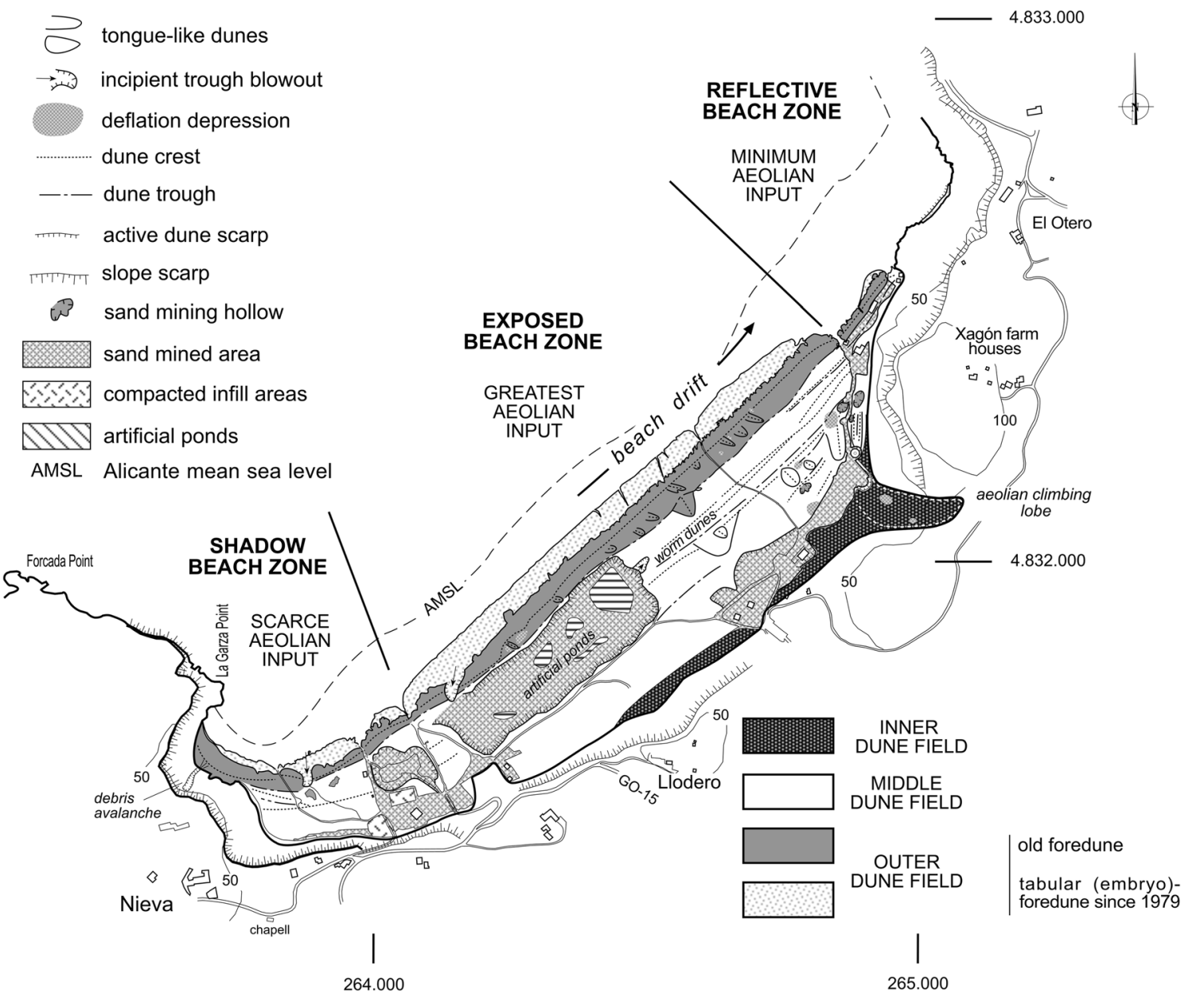

Fig. 3 Current aeolian dune field pattern with identified dune types in the Xagó beach/dune system, including areas altered by human activities 


\section{Materials and methods}

The mapping of the Xagó aeolian dune field was performed by means of a geographic information system (ArcGIS, ESRI Inc.) using a topographic map $(1: 5,000)$ from 2001 and orthophotographs from 2010 provided by the Cartographic Service of Asturias, via photo interpretation and field work to identify many of the smaller dune morphologies. Older stereo-photographs were inspected to establish the conditions prior to mining (1954, 1957 and 1970). Ridge crests and troughs, and the contours of tabular, foredune, climbing, longitudinal and tongue-like dunes, as well as anthropogenically modified areas were identified by stereoscopic photo analysis and field mapping.

Non-active zones in dune fields are usually colonised by dense vegetation, with trails generated by interspersed trampling activities. The latter were used for GPR profiling with different antenna sizes depending on the selected frequency (see Jol 2009). Three representative profiles (eastern, central and western) aligned NW-SE parallel to the onshore winds were chosen to reconstruct the internal architecture of the dune field. The selected cross-sections were first surveyed topographically using a GPS (Leica System 500) and then profiled by means of a MAL $\AA$ Geoscience ProEx GPR with data recordings at $0.2 \mathrm{~s}$ intervals. The best GPR results were obtained with antennas having central frequencies of 250 and 500 $\mathrm{MHz}$, both providing adequate resolution and penetration (Girardi and Davis 2010). The combined use of two antennas improved the interpretation of the GPR data because the two frequencies provide different but complementary information, although the $250 \mathrm{MHz}$ radargrams performed overall better in this dune field.

Radargrams are normally corrected topographically for interpretation. Nevertheless, some radargrams are presented without this correction. Thus, the eastern profile through the outer dune field, which includes the active foreshore, is reproduced without topographic correction to better visualise the complex sedimentary structures.

\section{Results}

\section{Dune types and dune fields}

In the Xagó dune field, three major elongated aeolian dune belts can be distinguished that run parallel to the beach from the inner slope to the backshore: an inner, a middle and an outer dune field (Figs. 1, 3, and 4a). The middle and outer dune fields comprise dune ridges, aeolian sedimentation being higher in the eastern and central sectors of the middle belt due to regular sand input from onshore winds. This sector is also favoured by the littoral drift towards the east (Fig. 3).
One of the most distinctive morphological features of the Xagó dune field is a climbing dune at the eastern side of the inner field. It is shaped in the form of a lobe dune that narrows and increases in height both downwind (from NW) and laterally as it climbs onto the hillside that has a slope of approx. $30^{\circ}$, thereby forming a narrow sand prism with a triangular cross-section. The most important morphologies, however, are the narrow foredunes, which form high and usually vegetated ridges (Fig. 4a). In contrast to these, the linear dunes extending from the outer foredune crest towards the leeward side, which Cooper (1958) has called lee-projection dunes, are here named tongue-like dunes (Fig. 4b). Some isolated examples can be seen in the inner eastern area of the middle field. Other minor elongated dunes are the so-called worm dunes that are superimposed on the stoss side of the large dune ridge in the middle field (Fig. 4b). Such worm dunes have previously been reported by García-Novo et al. (1975) and Vallejo (2007) from the stoss side of transverse barchanoid dunes in the Doñana National Park of Huelva in southern Spain, where the dunes are larger and more active. The dunes of the outer field are composed of incipient foredunes comprising tabular and embryonic forms (incipient foredune) according to Hesp (1984) or sand sheets according to Psuty (1989). These are attached to the upper beach.

\section{Inner aeolian dune field}

This part of the Xagó dune field is characterised by climbing dunes that occupy an overall area of $24,800 \mathrm{~m}^{2}$. These are separated from the middle dune field by a smooth, approx. $20 \mathrm{~m}$ wide trough. The largest climbing dune has a lobate shape, is $120 \mathrm{~m}$ long and $60 \mathrm{~m}$ wide, and covers an area of $9,000 \mathrm{~m}^{2}$, being slightly arched in plan view along a small NW-SE elongated valley, which has facilitated aeolian sand intrusion upwards and coincident with the beginning of the eastern profile (Fig. 1), thereby generating a depositional lobe (Fig. 3). Continuing westwards, it is replaced by a regular sand sheet where the hillside slope decreases. Being superimposed on the back slopes of the aeolian dune field, the climbing dunes act as topographic obstacles, such that the form reduces the former slope. Thus, this dune type has a triangular transverse shape.

\section{Middle aeolian dune field}

This dune field occupies the largest area $\left(215,300 \mathrm{~m}^{2}\right)$ and features a broad and continuous ridge with a maximum height of $20.7 \mathrm{~m}$ and an average width of $200 \mathrm{~m}$. The area is densely colonised by continental vegetation, the dunes being referred to as secondary (Psuty 2004) or grey dunes (Favennec 2002). The area has a smoothly rounded, convex topography that, at its eastern end, splits up into two parallel ridges (Fig. 3). The inner ridge is highly irregular due to tongue-like and 


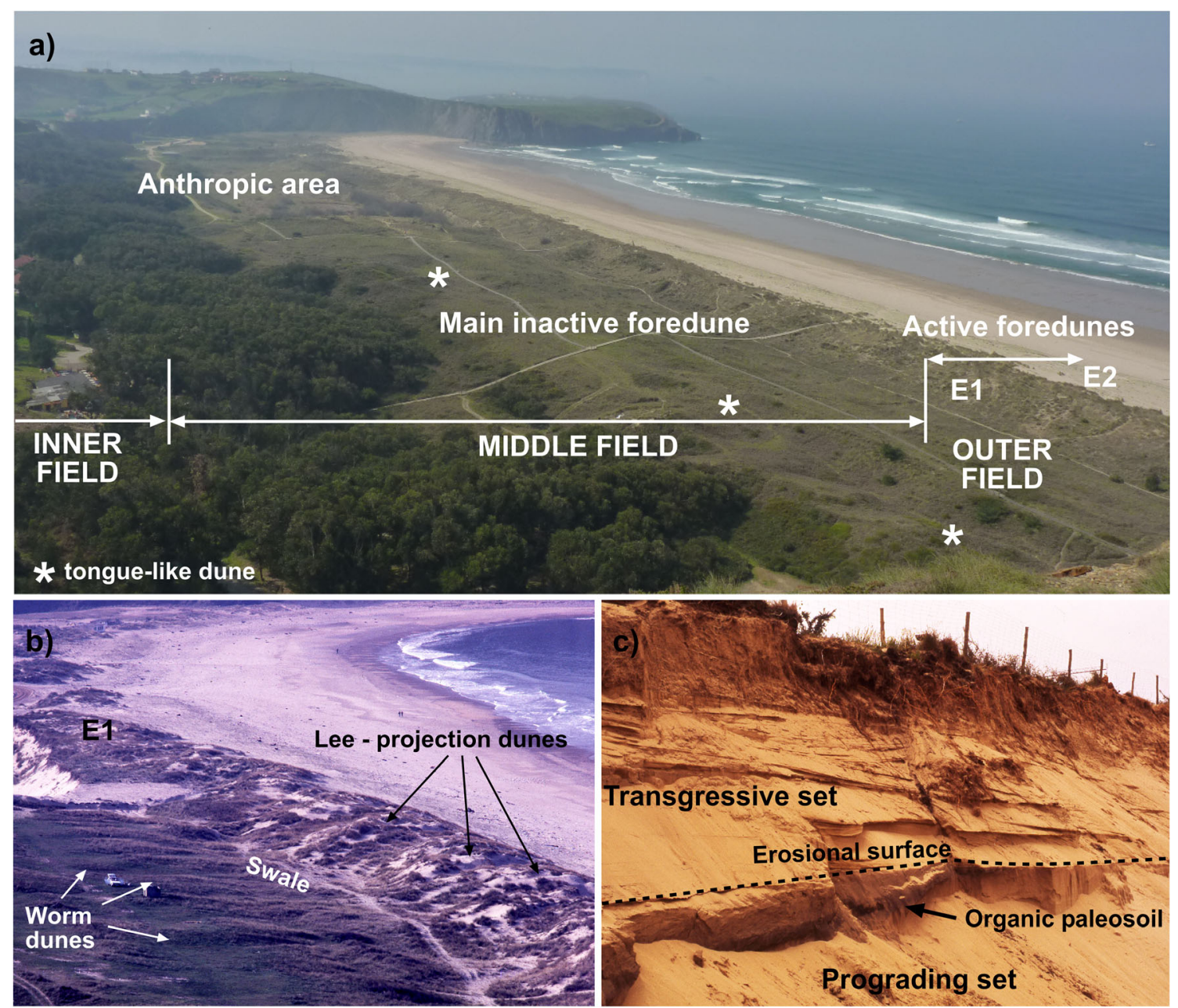

Fig. 4 a Oblique view of the beach/dune system showing the different sectors. b Outer dune field with foredune and lee-projection dunes. This photograph from 1983 also shows the worm dunes on the stoss side of the

longitudinal dunes, whereas the outer ridge is overall larger (Fig. 4a). On the stoss side, several superimposed small elongated ridges (decimetres in height and several meters in length) can be distinguished as worm dunes. These are aligned perpendicular to the main dune ridge (NW-SE), are semi-cylindrical in transverse cross-section and regularly arranged one next to the other. It is very difficult to recognise these small ridges on the ground because they are densely vegetated by shrubs and other vegetation, but they are easily identified on panoramic pictures from the 1980s (Fig. 4b).

Three tongue-like dunes have developed on the foredune lee sides of the eastern middle field (Figs. 3 and 4a), protruding in height slightly above the surrounding ground. Their contours are ovoid, with axes aligned NW-SE. They can be interpreted as roll-over deposits (cf. Bristow et al. 2000). Similar dune types have been observed in the dune fields along the erosional sandy coast of Aquitaine in SW France (Favennec and Mallet 2008). The formation of tongue-like dunes can also be triggered by trampling of the outer foredune, as can be seen in the neighbouring Salinas dune field (located $2 \mathrm{~km}$ to the west). middle dune field. c Transgressive and prograding sets separated by an organic palaeosoil. This separation line (erosion surface) is observed in both the Xagó and Salinas middle dune fields

Another two large longitudinal N-S aligned dunes occupy the foot of the western cliff of the flat Xagón hill. The eastern one is subdivided into two almost imperceptible longitudinal dunes separated by a shallow furrow (Fig. 3). These dunes are approx. twice as long as the tongue-like dunes (maximum of $100 \mathrm{~m}$ ) and $30 \mathrm{~m}$ in width. They began to form when the trough became disconnected from the transverse ridge. The formation of these dunes can be inferred to have begun when wave erosion opened a narrow corridor in the eastern corner of the beach, the NW-SE winds being diverted N-S by reflection against the sub-vertical western slope of the flat Xagó hill.

\section{Outer aeolian dune field}

Two dune belts can be distinguished in this dune field, which occupies a surface area of $81,900 \mathrm{~m}^{2}$ (Fig. 3). This irregular ridge was formed by the coalescence of grass-stabilised hillocks, including shadow dunes, hummocks and nebkhas (cf. Hesp 2002). Foredune development is tightly controlled by vegetation, principally by Ammophila arenaria, which is 
known to influence the formation and morphology of coastal dunes (cf. Hesp 2002; Davidson-Arnott 2010). At present, the stoss side of the foredune has an average width of $20 \mathrm{~m}$ from foot to crest. It is very irregular due to colonisation by Ammophila arenaria subsp. australis and through pedestrian trampling, which has resulted in the formation of some pyramidal dunes. The lee side is steep and narrow, with an average width of $30 \mathrm{~m}$ between crest and trough. It is colonised by other plant species such as Lagurus ovatus and Oenothera glazioviana.

When the outer foredune was being eroded in the second half of the last century, several lee-projection dunes or tonguelike dunes developed from the crest landwards. Their axes have a maximum length of $25 \mathrm{~m}$ and are aligned slightly oblique to the foredune direction, indicating that they were formed by WNW winds (Flor 1986). The main leeside trough (swale) is continuous and has a lax surface of 9-10 $\mathrm{m}$ in average width, separating the outer from the middle dune field. Locally, but more frequently in the central area, some tongue-like dunes overlie this swale in the SE (Figs. 3 and $4 \mathrm{~b}$ ).

The incipient foredune (Fig. 4b) occupies a surface of $42,335 \mathrm{~m}^{2}$ and has developed since 1979 (Flor-Blanco et al. 2013). It is characterised by flat surfaces that gently slope seawards and imperceptibly merge with the backshore. Storm waves can excavate a several decimetre high scarp along the upper beach limit. Sand dune pioneer vegetation is incipient and constituted mainly of Elymus farctus subsp. boreatlanticus, accompanied by Eryngium maritimum, Calystegia soldanella, Euphorbia paralias, Cakile maritima, Salsola kali, Polygonum maritimum, Pancratium maritimum and occasionally Ammophila arenaria (García-Albá and Morey 1981). The sparse dunes, which increase in height relative to the associated foredune, have the appearance of many small ephemeral shadow dunes. At the eastern end, a disconnected patch of tabular dune with a maximum surface of $1,000 \mathrm{~m}^{2}$ has formed since 1979 but has been eroding rapidly over the past 15 years.

\section{GPR profiles}

The main subsurface architecture can be clearly reconstructed from the radargrams, allowing the migration and, hence, the evolution of the dune field to be inferred in concordance with the surface morphology (Figs. 5, 6, and 7). The longest and most detailed profile was obtained in the eastern sector (Fig. 5) by combining several profiles from the upper beach to the inner climbing dunes. Such continuity was not possible along the central and western profiles (Figs. 6 and 7) because the middle and outer dune fields had been intensively mined for 50-80 years during the last century. In the western sector, the sedimentary volume is scarce because of the very effective shadowing of the beach from wind action, as a consequence of which very little sand is deflated (cf. Flor-Blanco et al.
2013). Moreover, most of the radargrams reveal cross-stratification accreting upwards and migrating to the north, suggesting general accretion from the inner dune areas to the beach from the onset of sedimentation.

Only the climbing dunes were generated by deflation of the old beach when sea level was higher than the present, the deflated sands having been transported up and against the slope. These relatively broad and thin aeolian sand sheets are represented by small-scale structures that reveal dome-like structures consisting of accreted laminae, the main stoss sides being conformably steep relative to the hill slope (Fig. 5, section 1). Some radar facies are high-angle and can be interpreted as grain-flow and/or grain-fall cross-strata.

The transitional swale between the inner and middle dune fields has a wide concave surface below which sub-horizontal and undulating radar reflections with diffractions of rooted and buried vegetation are revealed (Fig. 5, section 2a). Where the dune extended to the beach (Fig. 5, section 2b), the migrating sand has built two ridges. Stoss and lee laminae (both sloping towards the sea but at different angles) can be clearly identified. Topographically, this aeolian set is represented by a high ridge (Fig. 5, sections $2 \mathrm{~b}$ and $3 \mathrm{a}$ ) that displays a seaward dipping erosional surface at its base (Fig. 5, section 3a). Such scarps have also been noted on other coasts (see Bakker et al. 2012), and a similar surface was identified in a trench in the neighbouring Salinas dune field, where the aeolian dune fields have a comparable structure (Fig. 4c). In the eastern sector, and consistent with the findings of Bristow et al. (2000) along the Norfolk coast of the UK, some roll-over deposits are generated in the form of the aforementioned three tongue-like dunes.

The old erosion surface was subsequently covered by a new sand sheet characterised by a low ridge with concordant and convex reflectors representing moderate low-angle lee surfaces. This inner low ridge (Fig. 5, section 3b) evolves about $10 \mathrm{~m}$ northwards into a smooth ridge. The upper $2-3 \mathrm{~m}$ of the dune displays continuous convex, sub-parallel and low-angle reflectors, the lower sediment layers showing moderately inclined, downwind dipping slip faces. Seawards, a high ridge represents the middle aeolian field (Fig. 5, section 3c, Figs. 6 and 7) with seaward dipping high-angle leeside laminae on the outer slope. The general large-scale convex internal structure is consistent with the broad complex surface topography, although the uppermost reflections are irregular, similar to bio-topographic accumulations (cf. Bristow et al. 2000). The stoss side of the high ridge comprises moderately to low-angle seaward dipping clinoforms that are very continuous beneath the trough (Fig. 5, section 4a, Figs. 6 and 7) and the active foredune (outer dune field). The trough is represented by low-angle, discontinuously dipping reflectors and a generally smooth concave shape that has a more contrasted topography. The final dune typology is associated with a less than $5 \mathrm{~m}$ thick sand sheet, which decreases in thickness 


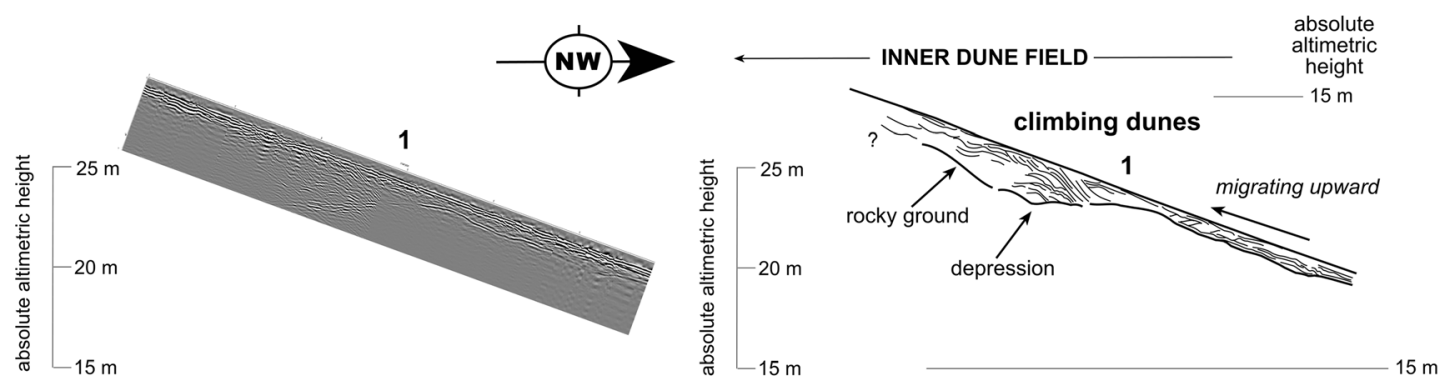

2b
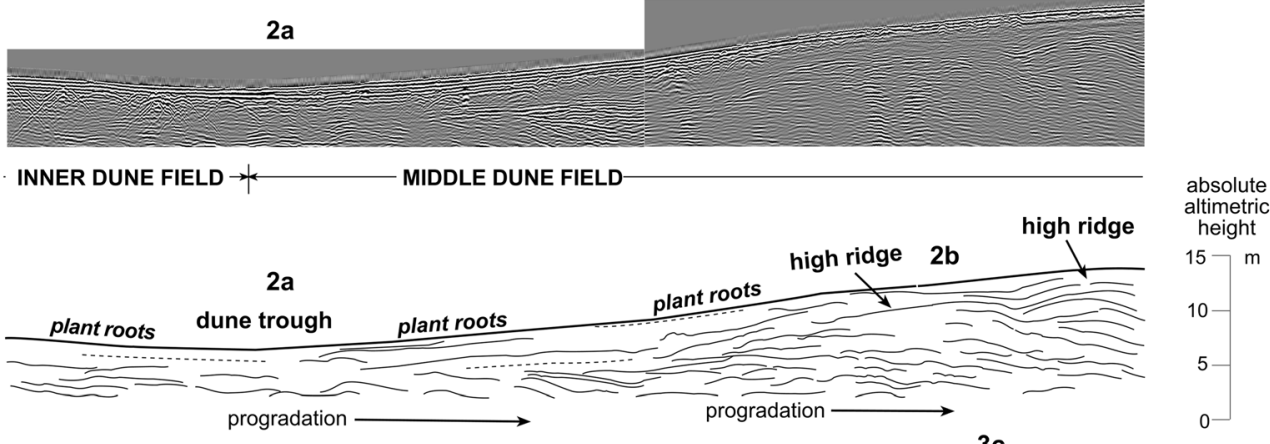

$3 c$

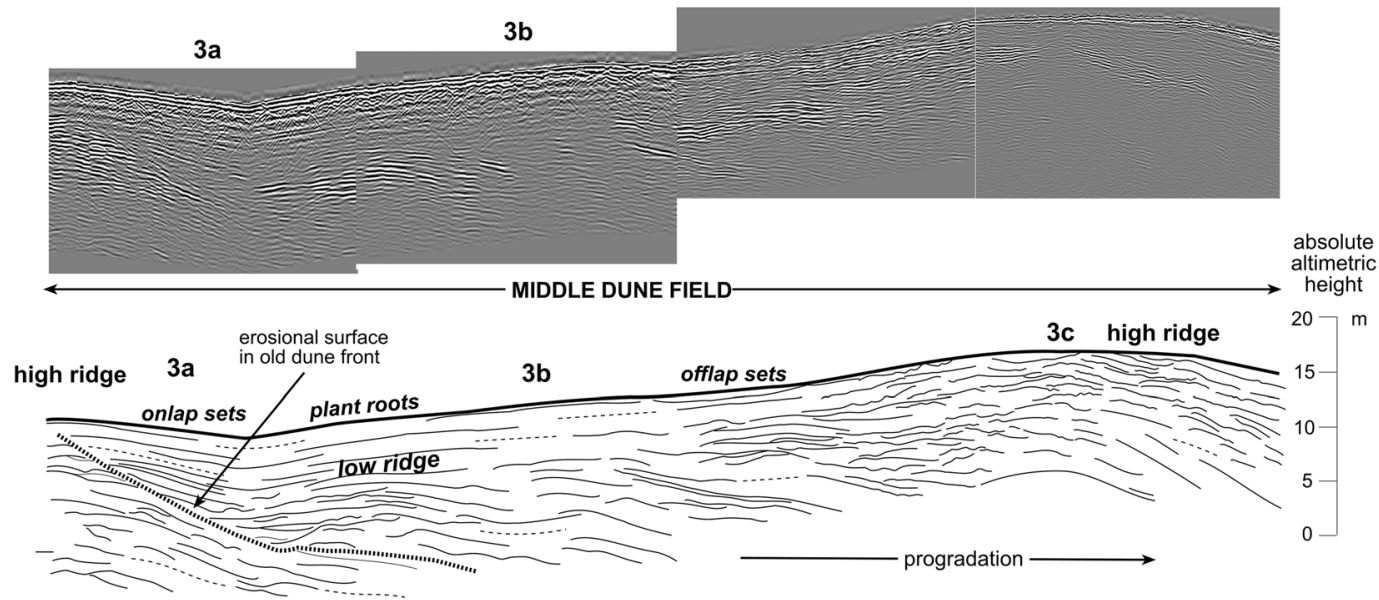

$4 a$

$4 b$
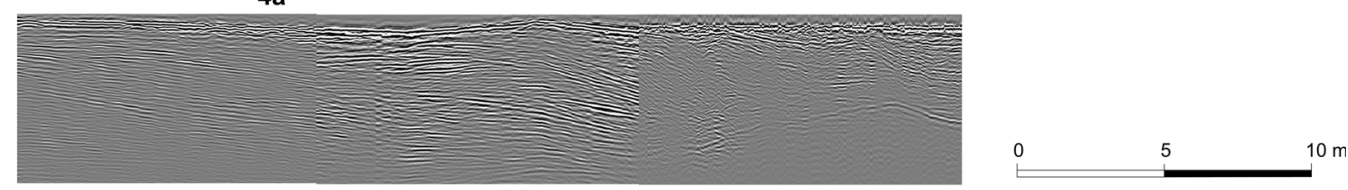

- MIDDLE DUNE FIELD $\rightarrow \longleftrightarrow$ OUTER DUNE FIELD $\longrightarrow$

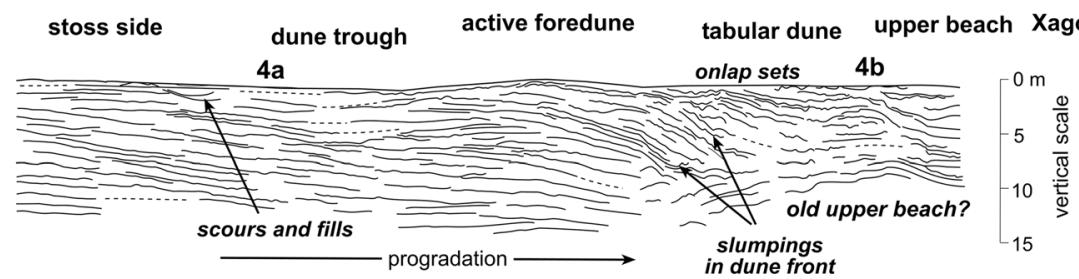

Fig. 5 Eastern GPR profile showing the reconstructed transverse section in four sections (Fig. 1) obtained using a $250 \mathrm{MHz}$ antenna (pulse velocity $0.14 \mathrm{~m} \mathrm{~ns}^{-1}$ ). Only the outer dune field with the active foreshore is reproduced without topography to improve the visualization of the complex sedimentary structures, especially in the outer dunes 


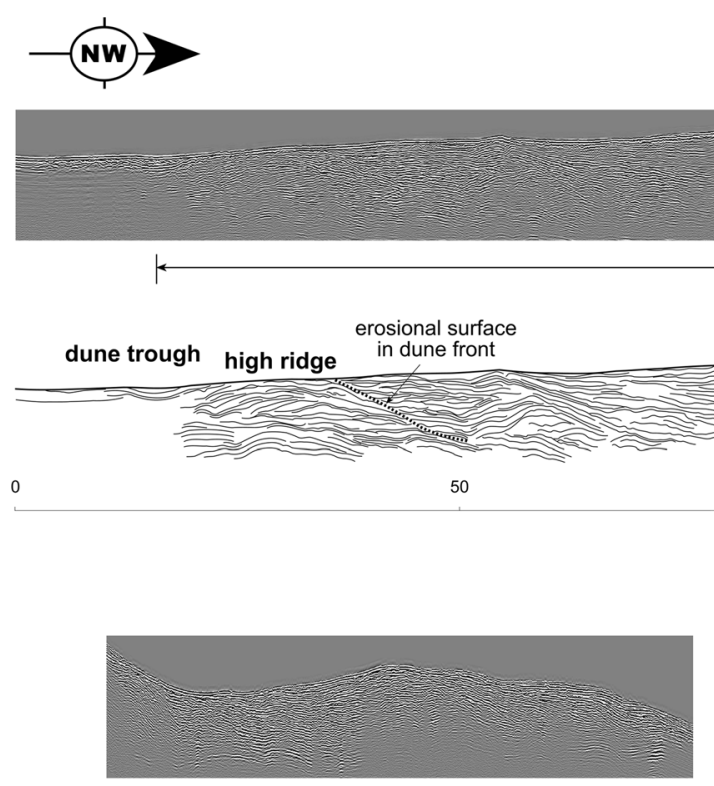

\section{MIDDLE DUNE FIELD}

high ridge
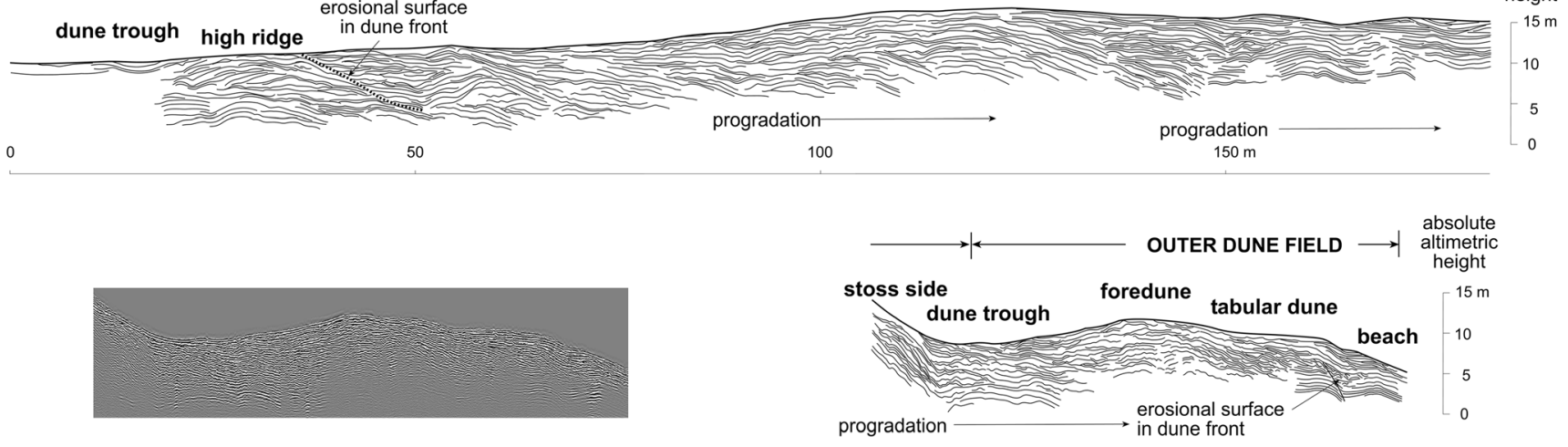

$50 \mathrm{~m}$

Fig. 6 Simplified reconstruction of the central profile, where the identification of an erosion surface in the inner middle aeolian field is essential for the understanding of the depositional interruption during the post-Flandrian transgression

towards the western dune field. Reflectors are discontinuous concave- and convex-up, undulating due to root concentrations from dune vegetation (Figs. 6 and 7).

In the case of the established foredune, the stoss side is made up of high-angle, irregularly undulating reflectors, some of which are slump structures, whereas others represent an old erosion surface generated by cyclical erosion and accretion processes linked to beach dynamics (Figs. 5, 6, and 7). This outer belt has been overprinted by modern incipient foredunes. Furthermore, incipient foredunes that partly cover the stoss sides of the foredunes proper increase in size towards the upper beach. The main internal stratifications are irregular, minor erosion sets dipping at high to moderate angles. They are covered by almost continuous very low-angle reflectors along with undulations caused by pioneer vegetation (Figs. 5, 6, and 7). Along the western profile, a tabular dune
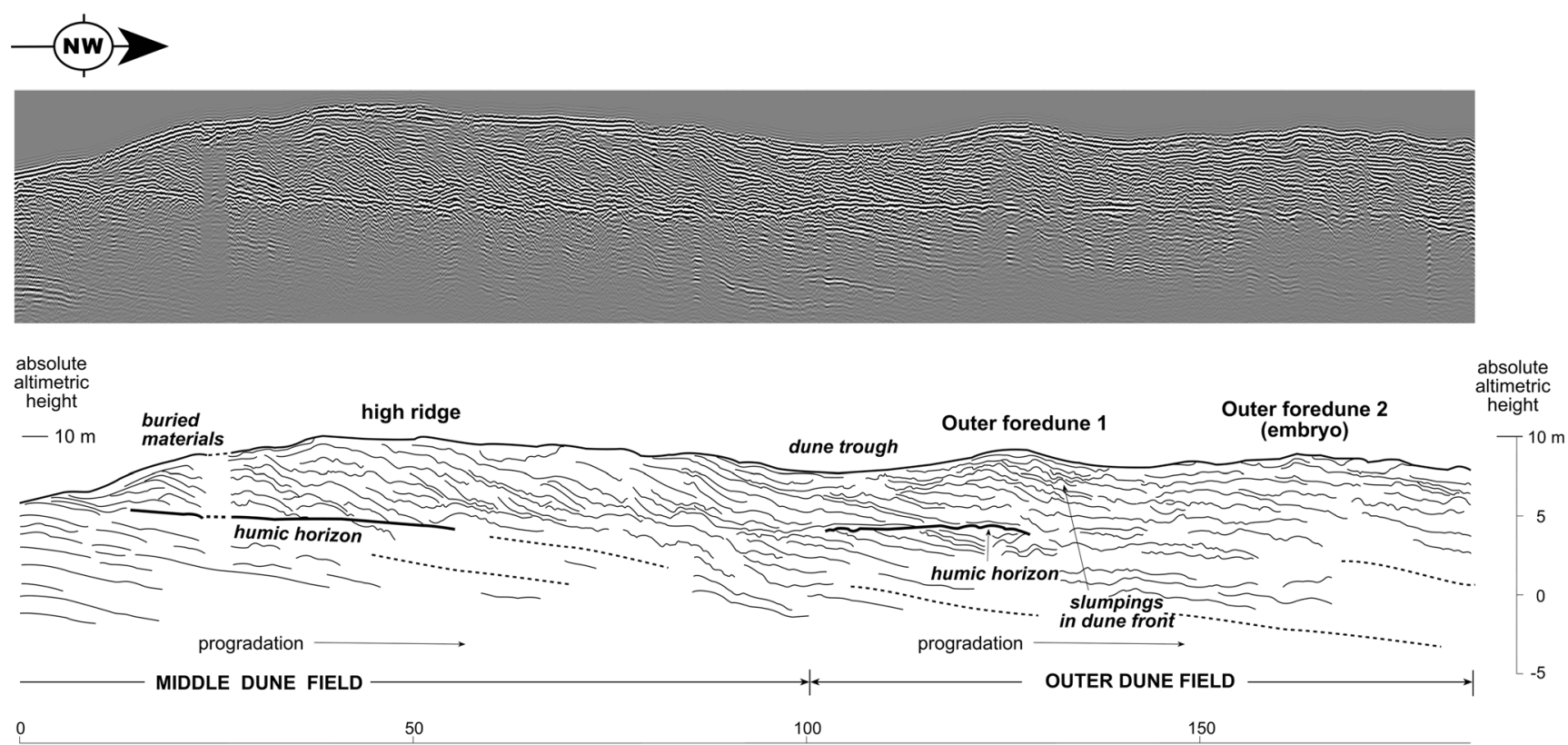

Fig. 7 Western profile showing the humic horizon and the prograding dune 
or incipient foredune in the outer dune field is partly underlain by what is interpreted to represent a discontinuous organic horizon (Fig. 7).

\section{Discussion}

Previous works on dune typologies in Asturias, Cantabria and Galicia (Cantabrian coast) have involved the characterisation of dune morphologies (Flor 1981, 1992; Flor et al. 2011), including their classification and characterisation using a hierarchical model applicable to temperate rocky coasts (Flor 1998). The fundamental requirements for the formation of coastal sand dunes are an abundant sediment supply and sufficiently strong wind to transport it from the beach to the hinterland (e.g. Łabuz 2005, Polish west coast). These requirements were guaranteed during the late Holocene because the Nalón fluvial system supplied large sand volumes that were transported alongshore by littoral drift (Flor 1978) and, along stretches of sandy beach, deflated by winds blowing from the first and fourth quadrants. The southerly winds did not contribute to the formation of dunes due to the vertical back cliff. In the case of the Xagó dune field, sand was supplied to the beach by ocean waves from the persistent eastward directed littoral drift (Flor-Blanco et al. 2013). Because the western beach sector is sheltered, aeolian sedimentation is very limited (energetic shadow). Towards the wider central sector, the beach is more energetic and the dune field thus receives large volumes of drift sand. The narrow eastern sector, in turn, is dominated by wave reflection, as a result of which the nearby foot of the cliff remains sediment starved (Fig. 3).

The analysis of dune morphology and reconstruction of the internal architecture by means of GPR enabled detailed links to be established between the evolution of the Xagó dune field and specific eustatic events (Figs. 8 and 9), which can be extrapolated to other areas of the wider region. The development of the Xagó dune field commenced as sea level fell after reaching its Holocene maximum at the terminal Flandrian transgression (Fig. 8a). The sedimentary terrace of Bañugues, located $8.5 \mathrm{~km}$ to the ENE, was cut in the course of the same transgression that reached a maximum absolute height of 5.5-6.0 m, and was topped by a highstand beach deposit ( $<1.0 \mathrm{~m}$ thick) containing Asturian artefacts (picks) of Mesolithic age (Rodríguez-Asensio and Flor 1979). In western Cantabria (130 km to the east), Mary (1992) dated this maximum sea-level stand at 5,880 years BP, thus marking the end of the regional transgression at approx. 5-4 ka. In central Portugal, the coastline of this transgression is located $1 \mathrm{~km}$ inland from the present shore (Danielsen et al. 2012). These ages are in excellent agreement with the notion of Pye et al. (2007) that, in England and Wales, the Holocene dunes formed over the last 5,000 to 6,000 years. Along the west coast of Ireland, the present-day dunes also formed over the same time interval, commencing just after the mid-Holocene maximum sea-level stand that reached a height of $+3 \mathrm{~m} \mathrm{OD}$, as documented from the coast of the County of Antrim (Carter et al. 1989).

With falling sea level, sediment is transferred onshore to accumulate as beach ridges and dunes. During highstands, much of the river-supplied sediment is trapped within estuaries (e.g. Gracia et al. 2006, Atlantic coast of SW Spain), being released only by a lowering of the base level caused by a fall in sea level, which results in a greater supply of sand to the coast. Logically, the availability of sediment for dune formation is a function of sediment transport in the nearshore environment during periods of beach accretion (Hesp 1999). As a result, aeolian dune fields can be generated more rapidly. In the present case (inner and middle dune fields), the following conditions favoured dune formation: forced regression, a high sand supply, a suitable wave climate coupled with strong onshore winds, and a dissipative beach morphology (Hesp and Short 1999). In response, multiple shore-parallel dune ridges were generated on a prograding shore backed by a steep rocky coast. The evolution of this aeolian dune/beach system is similar to that considered by Pye and Tsoar (1990), in which landward sand movement is followed by seaward dune progradation as sea level falls. This evolutionary model is generally representative of late Holocene dune/beach systems along temperate rocky shorelines.

From the maximum Flandrian sea-level position (Fig. 8a), the inner aeolian dunes (climbing dunes) were generated soon after sea level began to fall (Fig. 8b). The dry upper beach of the eastern half of the Xagó beach developed as a narrow belt, thus deflecting the sand and generating the climbing dunes. One of these dunes migrated upwards through a very small, gently sloping valley to form a flat lobe with shallow depressions on its upper surface (Fig. 9a). Subsequently, as sea level fell, an initial ridge was built (foredune), leaving a relatively wide swale between this new dune and the inner climbing older dunes (Figs. 8c and 9b). To the southwest, this process formed a large ridge (Figs. 5 and 6) under a persistent accretionary set of processes (Fig. 8c). The formation and progradation of coastal dunes are generally associated with large sedimentary inputs (Davis and FitzGerald 2004). In the study area, the sediment is supplied by the Nalón and Narcea rivers, currently having a catchment area of $4,921.09 \mathrm{~km}^{2}$ and an average annual runoff of $81 \mathrm{~m}^{3} \mathrm{~s}^{-1}$ (http://hercules.cedex. es/anuarioaforos/afo/estaf-todalacuenca.asp?cdr1=0119).

A later rise or stillstand of the sea level resulted in low sedimentary inputs, as a consequence of which the ridge was partly eroded (Figs. 8d and 9c). This is documented by a pronounced internal and oblique erosion surface in the radargrams (Fig. 5, section 3a, and Fig. 6). A similar situation was directly observed when trenching in the neighbouring Salinas dune field. It exposed an erosional surface above a humic horizon and an upper transgressive sequence of aeolian 
a)

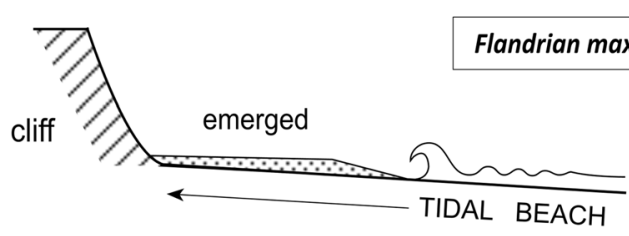

b)
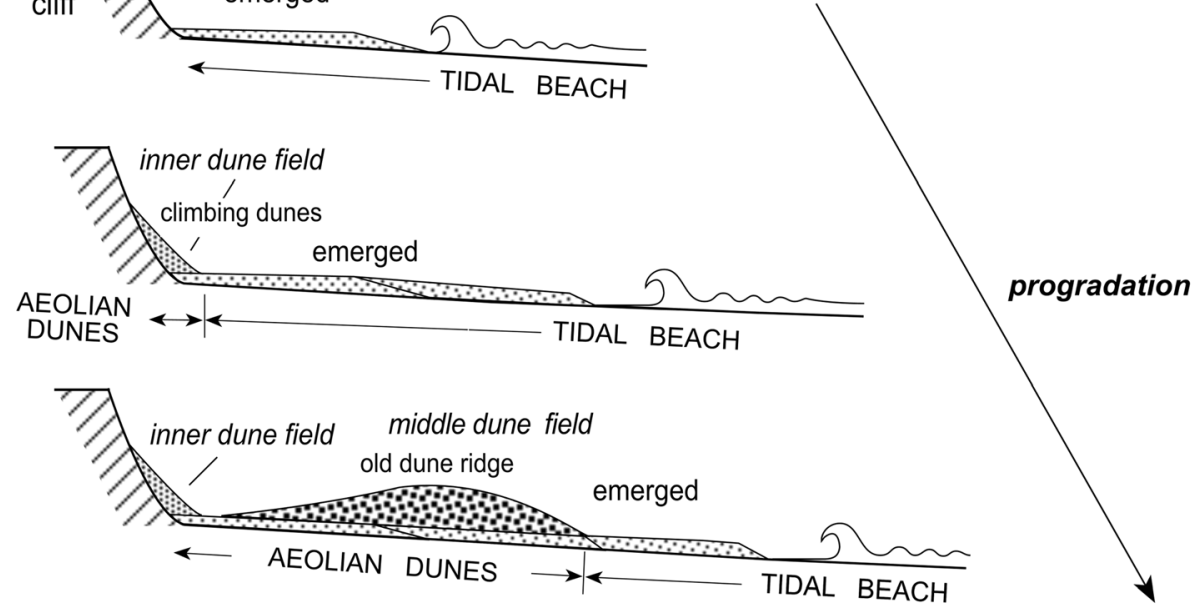

d)
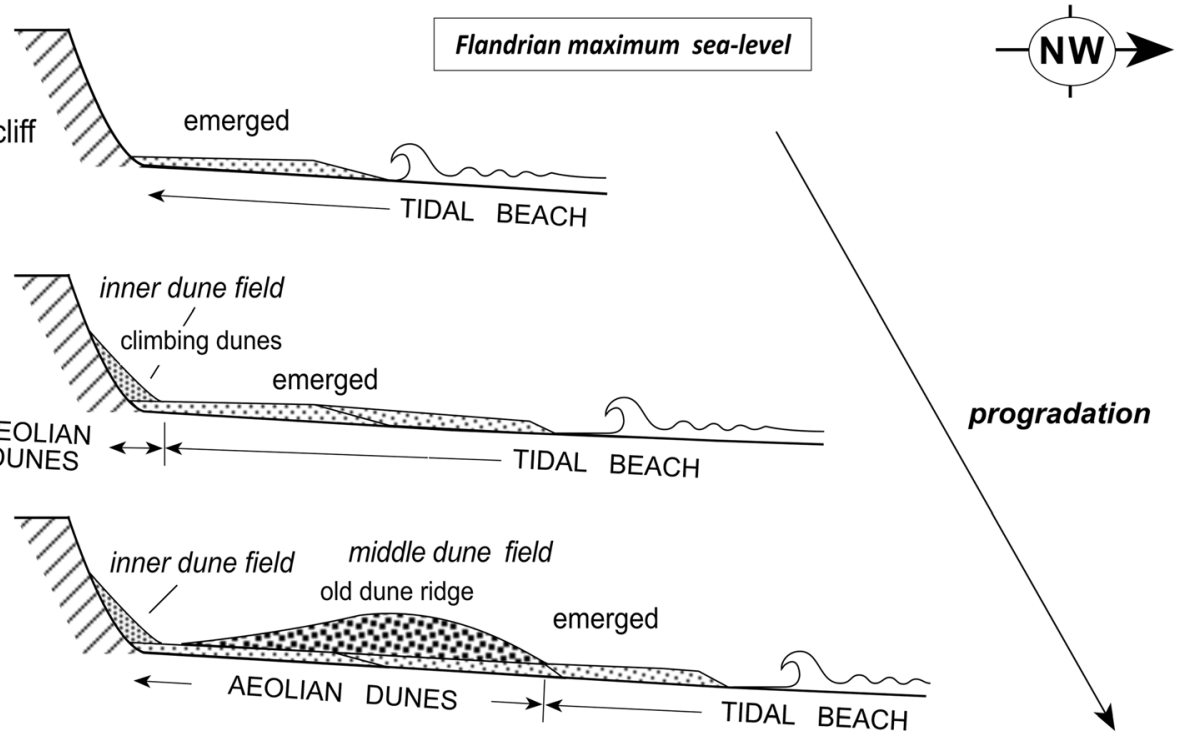

c)

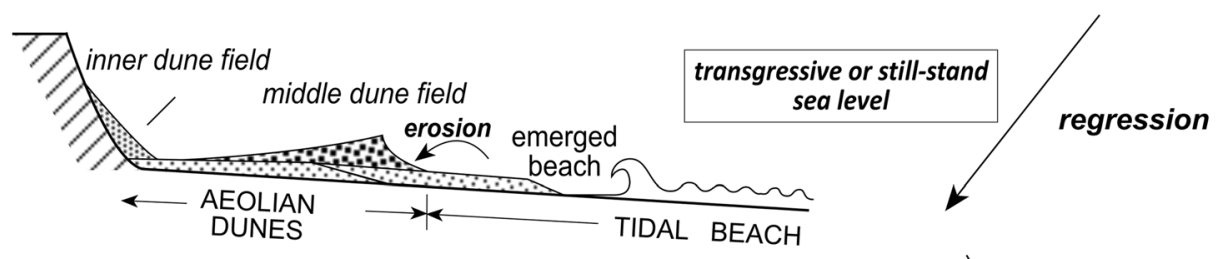

e)

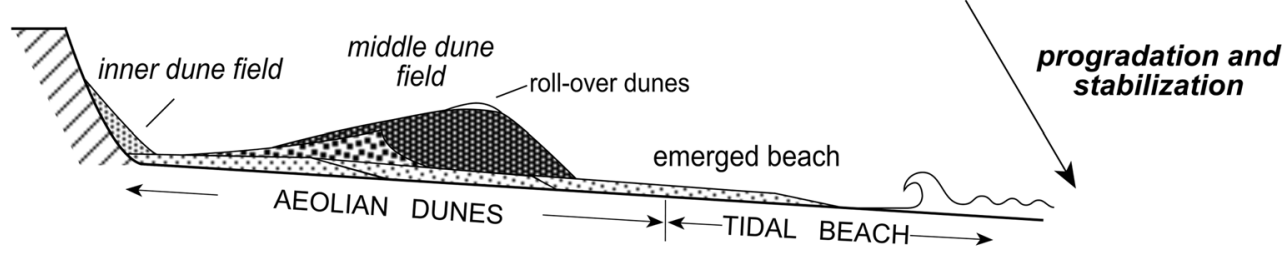

f)
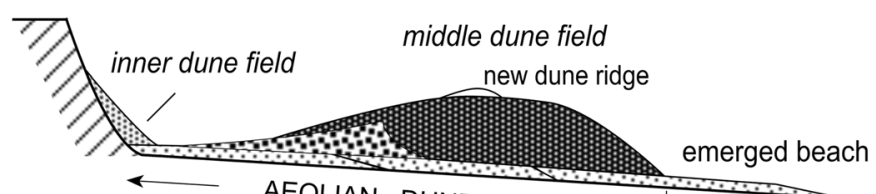

g)

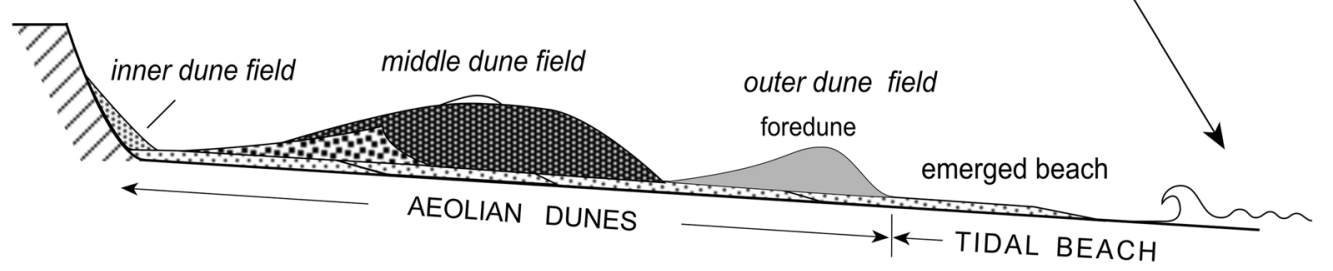

h)

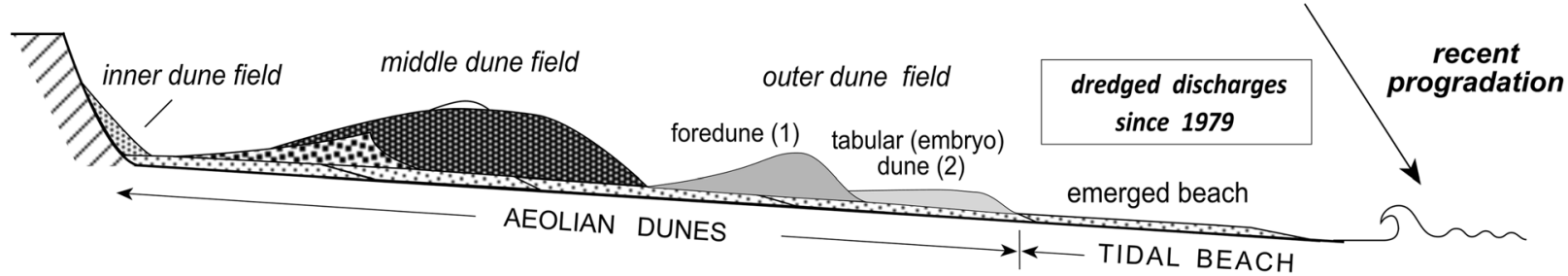

Fig. 8 Simplified reconstruction (without scale) of the evolution of the Xagó dune field after the maximum Flandrian transgression, when there was only an emerged beach (a), to the present situation (h)

sands (cf. Fig. 4c). The transgressive pulse in the middle dune field can be inferred from or equated with similar outcrops in SW Galicia described by Martínez Cortizas and Costa Casais (1997), which were dated at approx. 2,000 years BP, and the western Andalusian coast (Huelva) described by Borja and Díaz del Olmo (1996). The current process of erosion along the Cantabrian coast, where the dunes are suffering significant recession due to low sediment inputs in response to a gradual 
a)

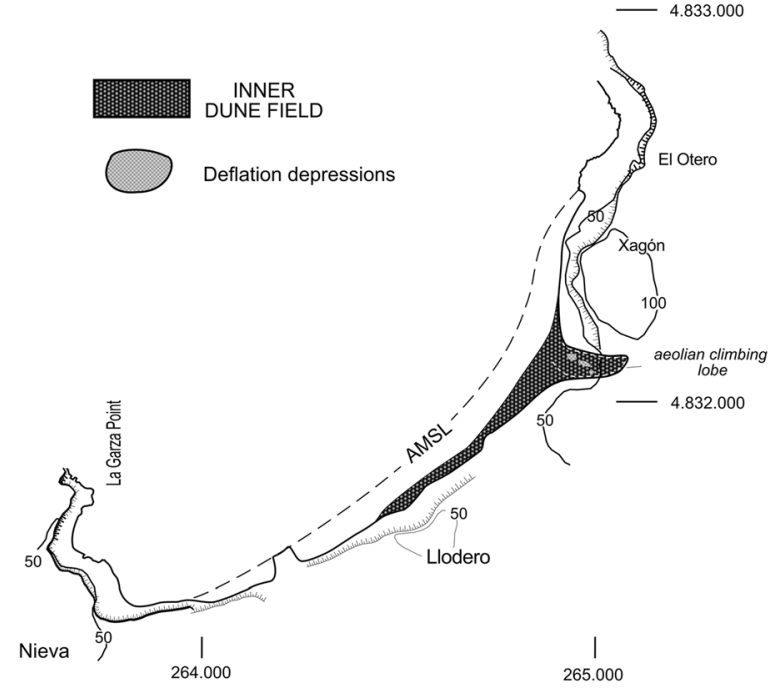

c)

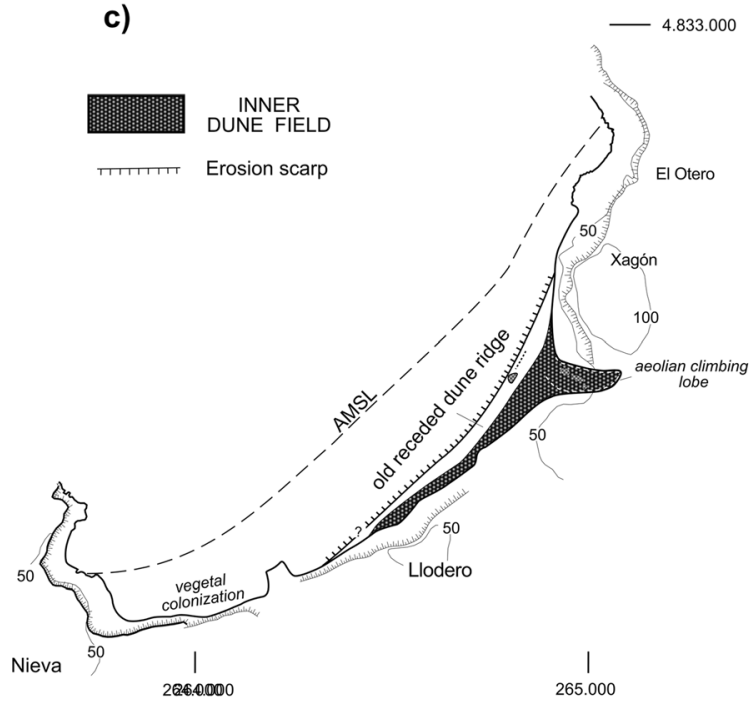

e)

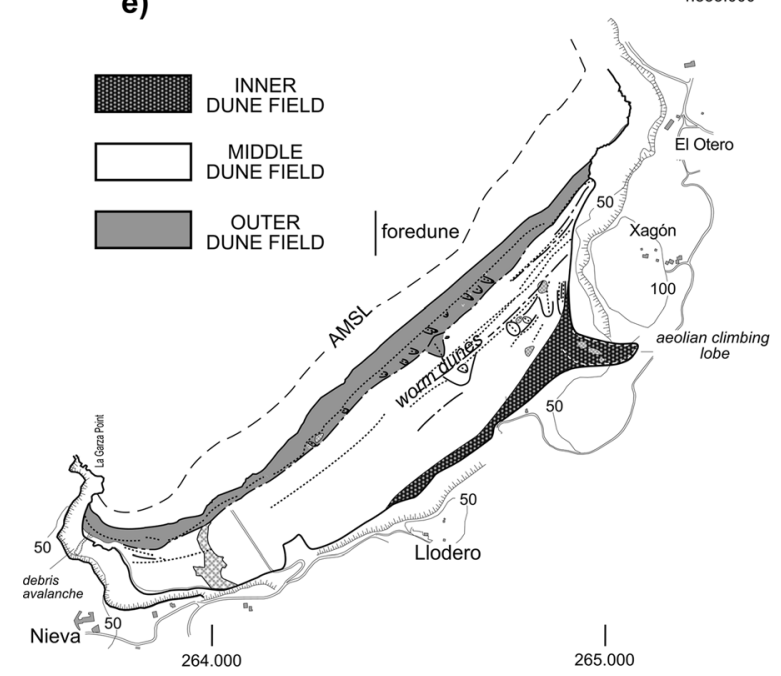

b)

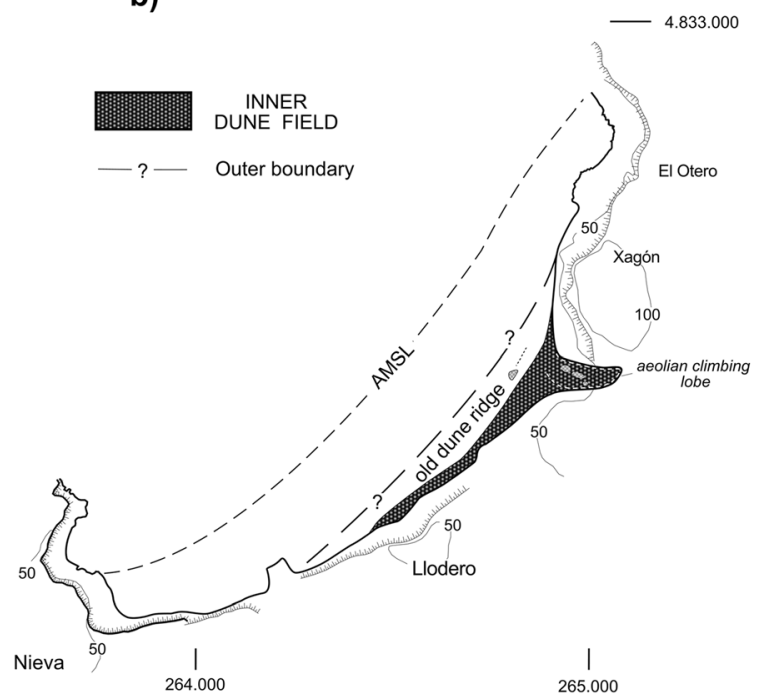

d)

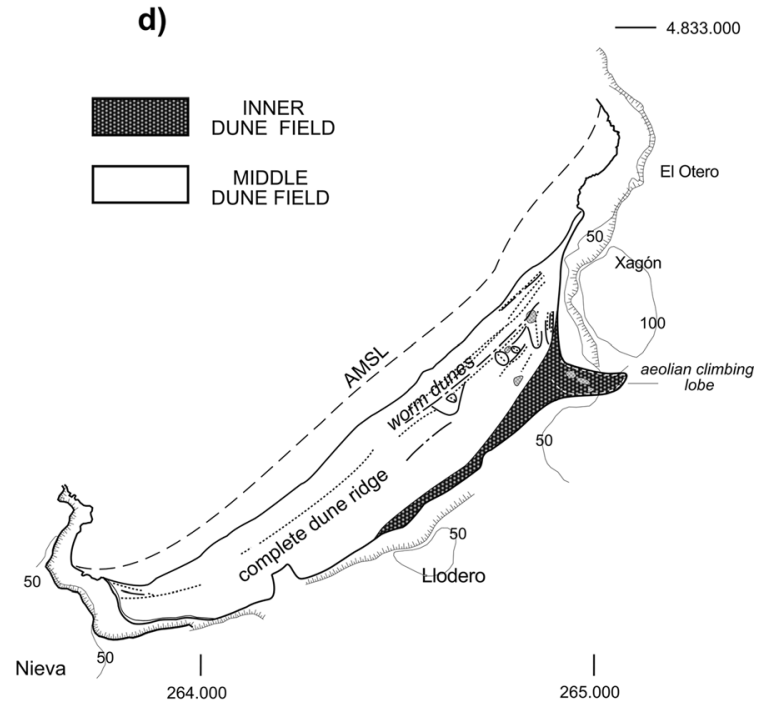

f)

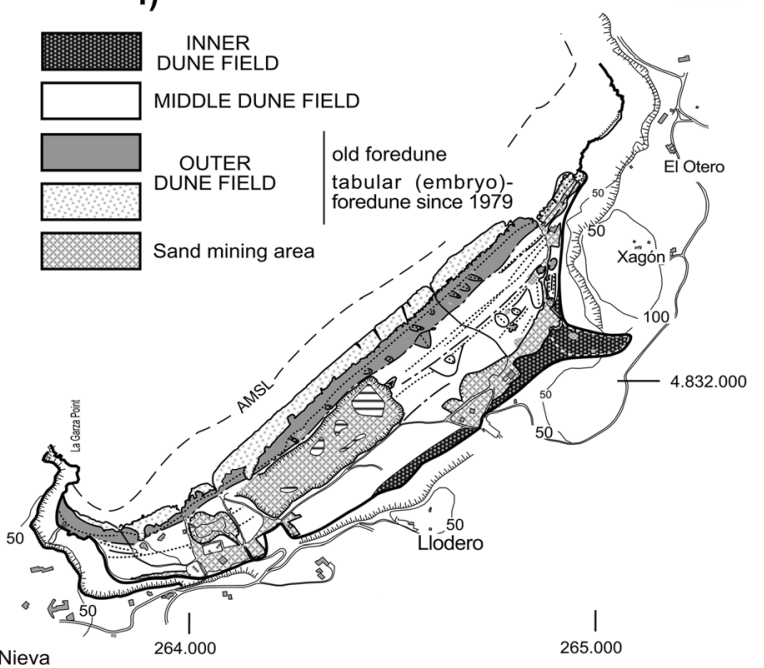


Fig. 9 Plan views of the evolutionary stages from the formation of the old beach (a) to the complex dune field of today (f)

sea-level rise, can be considered to represent a modern analogue of the situation recorded in the radargrams. Such massive erosion also occurs during intense destructive events such as the severe storms recorded on the Cantabrian coast during February and March 2014 (Flor et al. 2014) - at Xagó, these caused dune recessions of between 3 and $11 \mathrm{~m}$, and erosional dune scarps of up to $3 \mathrm{~m}$ high.

In the middle field, several tongue-like dunes represent roll-over deposits (cf. Bristow et al. 2000) of the type also documented by Favennec and Mallet (2008) along the retreating coast of Aquitaine (western France). In the easternmost beach sector, the formation of these dune types is linked to sand deflation in combination with north-westerly winds and the retreat of the foredune front (Fig. 8e) over an extended period of relative sea-level stability accompanied by beach erosion. Subsequent sea-level rise and fresh sediment supply promoted onlapping sedimentation (Figs. 5 and 6), which covered the previous morphology and favoured the construction of a larger and wider ridge in the form of a new foredune (Figs. 8e and 9d). The final phase affecting the entire middle dune field consisted of stoss-side sedimentation and worm dune formation in response to NW winds and the absence of topographic obstacles and vegetation. In the western beach sector, the sand volume decreased, resulting in less accretion due to the shadowing effect of the western headland. The increase in the height of the dune ridge here was caused by gradual accretion of the stabilised dune in the course of time (cf. Bristow and Pucillo 2006).

The colonisation of the supratidal beach by vegetation in the western sector (Fig. 9d) most probably indicates a temporary lack of sedimentation that, in the next evolutionary stage, promoted the formation of a humic horizon $1.0 \mathrm{~m}$ above the actual phreatic level (Fig. 7). The subsequent sea-level fall left the dune ridge within the shadow zone stranded with little further aeolian sand input. Moreover, the swale between the northern side of the middle dune field and the lee side of the old outer foredune most likely reflects a prolonged period of stable sea level (Fig. 4b). During the final sea-level fall, this outer foredune was formed (Fig. 9e), occupying a narrow belt along most of the beach. The increase in foredune elevation is best explained by a decrease in the rate of coastal progradation when sea level stabilised. This provides more time for dry sand to be blown from the beach to the foredune (cf. Bristow and Jol 2003). In addition, the inner fringe of the foredune is dotted with many tongue-like dunes, which extend landwards from the crest in the form of roll-over deposits (Figs. 8f and 9e). Internally, the dune is characterised by steep and slumped laminae sloping towards the beach, along with some erosional surfaces (Fig. 5, section 4b, Figs. 6 and 7).

Sand mining began around 1940, initially in the western sector and on a small scale, but intensified after 1945 in connection with steel production in nearby Avilés. Much of the central and western foredunes, and some inner areas in the western third of the upper beach, were destroyed by this activity (Fig. 9f), which also included the extraction of beach gravels. Until 1979, large volumes of clean fine siliciclastic sands were extracted, producing a large depression in the main ridge of the middle aeolian dune field that, in some places, reached the phreatic level. In addition, during the 1970s, the foredune front showed signs of natural erosion with little seasonal accretion (Figs. 8h and 9f). However, the fresh supply of sand and gravel from sediment dredged in the Avilés estuary since 1979 has resulted in several metres of vertical accretion along Xagó beach, thereby forming the incipient foredune exhibiting a terrace-like morphology (Flor-Blanco et al. 2013). This incipient structure becomes narrower towards the west and is detected in the GPR profiles as a slightly seaward dipping sand sheet.

\section{Conclusions}

The combination of detailed morphological dune mapping and GPR profiling has enabled the reconstruction of the evolution of the Xagó dune field since mid-Holocene times in relation to sea-level fluctuations and changing sediment inputs. The main sequence of events was:

- Formation of the inner dune field after the mid-Holocene sea-level highstand.

- Formation of a foredune ridge (the middle dune field) during the subsequently falling sea level.

- Temporary beach erosion and landward displacement of the erosion limit in the central and eastern sectors, and the formation of a humic horizon in the western sector during a minor transgressive phase or sea-level stillstand, which was associated with severe storms and a decrease in sediment supply.

- Accretion during a subsequent sedimentation phase with the formation of tongue-like dunes. The middle dune field was fully deposited, generating superimposed worm dunes and aeolian sedimentation over the entire back beach.

- Formation of a new foredune (old outer dune field) in the wake of a renewed sea-level fall. Intermittent erosional phases resulted in the development of the outer tonguelike dunes.

- Mining activity during the 1940s and 1950s affected the formation of the last foredune. From the 1960s to the 1980s, the western half of the middle dune field was destroyed by this activity.

- Fresh sediment supply from dumped dredged sands compensated foredune erosion towards the end of the 1970s 
and resulted in the formation of a new foredune that today constitutes the new outer dune field.

- The identification of transgressive and regressive events using the GPR method has resulted in a significant improvement in our understanding of the processes that affected the Cantabrian coast within the Holocene period.

Acknowledgements The authors thank two referees and the editors for their comments that greatly helped to improve the manuscript. Many thanks too to Luis Pando (University of Oviedo) for his help with the figures.

\section{Compliance with ethical standards}

Conflict of interest The authors declare that there is no conflict of interest with third parties.

\section{References}

Alonso A, Pagés JL (2007) Stratigraphy of Late Pleistocene coastal deposits in northern Spain. J Iber Geol 33:207-220

Araújo-Gomes J, Ramos-Pereira A (2015) The new CutSprof sampling tool and method for micromorphological and microfacies analyses of subsurface salt marsh sediments, Algarve, Portugal. Geo-Mar Lett 35:69-75

Bakker MAJ, van Heteren S, Vonhögen LM, van der Spek AJF, van der Valk B (2012) Recent coastal dune development: effects of sand nourishments. J Coast Res 28:587-601

Bigarella J, Becker RD, Duarte GM (1969) Coastal dune structures from Paraná (Brazil). Mar Geol 7:5-55

Borja F, Díaz del Olmo F (1996) Manto eólico litoral (MEL) de El Abalario (Huelva, España): episodios morfogenéticos posteriores al 22.000 BP. In: Pérez Alberti A, Martíni P, Chesworth W, Martínez Cortizas A (eds) Dinámica y evolución de medios Cuaternarios. Consellería de Cultura, Xunta de Galicia, pp 375-390

Bristow CS (2009) Ground penetrating radar in aeolian dune sands. In: Jol HM (ed) Ground penetrating radar: theory and applications. Elsevier, Amsterdam, pp 271-297

Bristow CS, Jol HM (eds) (2003) Ground penetrating radar in sediments. Geol Soc Spec Publ 211. Geol Soc Publ House, Bath

Bristow CS, Pucillo K (2006) Quantifying rates of coastal progradation from sediment volume using GPR and OSL: the Holocene fill of Guichen Bay, south-east South Australia. Sedimentology 53:769 788

Bristow CS, Pugh J, Goodall T (1996) Internal structure of aeolian dunes in $\mathrm{Abu}$ Dhabi revealed using ground penetrating radar. Sedimentology 43:995-1003

Bristow CS, Chroston PN, Bailey SD (2000) The structure and development of foredunes on a locally prograding coast: insights from ground-penetrating radar surveys, Norfolk, UK. Sedimentology 47:923-944

Bristow CS, Jones BG, Nanson GC, Hollands C, Coleman M, Price DM (2007) GPR surveys of vegetated linear dune stratigraphy in central Australia: evidence for linear dune extension with vertical and lateral accretion. Geol Soc Am Spec Pap 432:19-33

Buynevich IV, FitzGerald DM (2001) Styles of coastal progradation revealed in subsurface records of paraglacial barriers, New England, USA. J Coast Res Spec Issue 34:194-208
Buynevich IV, Jol HM, FitzGerald DM (2009) Coastal environments. In: Jol HM (ed) Ground penetrating radar: theory and applications. Elsevier, Amsterdam, pp 299-322

Carter RWG, Devoy RJN, Shaw J (1989) Late Holocene sea levels in Ireland. J Quat Sci 4:7-24

Cearreta A, Edeso JM, Merino A, Ugalde T, Ugarte FM (1990) Las dunas litorales de Barrika (costa occidental de Bizkaia). Kobie 19:77-83

Cearreta A, Alday M, Freitas MDC, Andrade C (2007) Postglacial foraminifera and paleoenvironments of the Melides Lagoon (SW Portugal): towards a regional model of coastal evolution. J Foram Res 37:125-135

Chust G, Borja A, Liria P, Galparsoro I, Marcos M, Caballero A, Castro R (2009) Human impacts overwhelm the effects of sea-level rise on Basque coastal habitats (N Spain) between 1954 and 2004. Estuar Coast Shelf Sci 84:453-462

Clemmensen LB, Andreasen F, Heinemeier J, Murray A (2001) A Holocene coastal aeolian system, Vejers, Denmark: landscape evolution and sequence stratigraphy. Terra Nova 13:129-134

Cooper WS (1958) Coastal sand dunes of Oregon and Washington. Geol Soc Am 72:1-169

Costas S, Alejo I, Rial F, Lorenzo H, Nombela M (2006) Cyclical evolution of a modern transgressive sand barrier in northwestern Spain elucidated by GPR and aerial photos. J Sediment Res 76:1077-1096

Danielsen R, Castilho AM, Dinis PA, Almeida AC, Callapez PM (2012) Holocene interplay between a dune field and coastal lakes in the Quiaios-Tocha region, central littoral Portugal. The Holocene 22: 383-395

Davidson-Arnott RG (2010) Introduction to coastal processes and geomorphology. Cambridge University Press, Cambridge

Davis RA Jr, FitzGerald DM (2004) Beaches and coasts. Blackwell, Malden

Edeso JM (1994) El relleno holoceno de la depresión de Zarauz. Lurralde $17: 115-152$

Favennec J (2002) Paysages des dunes littorales non boisées de la côte atlantique. In: Connaissance et gestion durable des dunes de la côte atlantique. Les Dossiers Forestiers, ONF, Paris, 11, pp 93-108

Favennec J, Mallet C (2008) Un atlas de l'aléa érosion marine réalisé dans le cadre de l'observatoire de la côte pour guider les choix d'aménagement de la côte sableuse d'Aquitaine. In: Proc Int Pluridisc Conf The Littoral: Challenge, Dialogue, Action. Thème 1, séance 2. Lille, France. http://www.meshs.fr/documents/pdf/ publications/actes/colloque littoral/Favennec.pdf

Feal-Pérez AM (2012) Evolución morfodinámica y procesos actuales en costas rocosas. PhD Thesis, University of Santiago de Compostela

Feal-Pérez A, Blanco-Chao R, Valcárcel-Díaz M (2009) Influencia de formas y procesos heredados en la evolución reciente y en los procesos morfodinámicos actuales en un sector de la costa rocosa: Punta Gallín, costa Cantábrica gallega. Rev Soc Geol Esp 22:67-78

Feal-Pérez A, Blanco-Chao R, Ferro-Vázquez C, Martínez-Cortizas A, Costa-Casais M (2014) Late-Holocene storm imprint in a coastal sedimentary sequence (Northwest Iberian coast). The Holocene 24:477-488

Fisher TG, Jol HM, Smith DG (1995) Ground-penetrating radar used to assess aggregate in catastrophic flood deposits, northeast Alberta, Canada. Can Geotech J 32:871-879

Flor G (1978) Relación entre la circulación costera y la distribución de sedimentos en la región de Cabo Peñas. Trab Geol 10:183-194

Flor G (1981) Las dunas eólicas costeras de la playa de Xagó. Trab Geol 11:61-71

Flor G (1986) Sedimentología de una duna lingüiforme en la playa de Xagó (Asturias). In: Proc IX Congr Nacional de Sedimentología, I. Salamanca, pp 317-328

Flor G (1992) Tipología, catalogación y procesos erosión/sedimentación de los campos dunares eólicos de Galicia (NO de España). Thalassas 10:9-39 
Flor G (1998) Classification and characterization of aeolian dunes in temperate rocky coasts. The Spanish Peninsular aeolian fields. In: Soares de Carvalho G, Veloso Gomes F, Taveira Pinto F (eds) Dunas da zona costeira de Portugal. Associação Eurocoast-Portugal, pp $29-42$

Flor G, Flor-Blanco G (2014) Raised beaches in the Cantabrian coast. In: Gutiérrez F, Gutiérrez M (eds) Landscapes and landforms of Spain. Springer, Dordrecht, pp 239-248

Flor G, Lharti S (2008) Estratigrafía y sedimentología del recubrimiento costero de la ciudad de Gijón (Asturias). Trab Geol 28:137-157

Flor G, Martínez-Cedrún P, Flor-Blanco G (2011) Campos dunares de Asturias, Cantabria y País Vasco. In: Sanjaume E, Gracia FJ (eds) Las dunas en España. Sociedad Española de Geomorfología, pp $127-159$

Flor G, Flor-Blanco G, Flores-Soriano C (2014) Cambios ambientales por los temporales de invierno de 2014 en la costa asturiana (NO de España). Trab Geol 34:97-123

Flor-Blanco G, Flor G, Pando L (2013) Evolution of the Salinas-El Espartal and Xagó beach/dune systems in north-western Spain over recent decades: evidence for responses to natural processes and anthropogenic interventions. Geo-Mar Lett 33:143-157

García-Albá J, Morey M (1981) La vegetación de las dunas litorales y su relación con la morfología dunar y el gradiente de influencia marina. Mediterránea 5:3-22

García-Artola A, Cearreta A, Leorri E (2015) Relative sea-level changes in the Basque coast (northern Spain, Bay of Biscay) during the Holocene and Anthropocene: the Urdaibai estuary case. Quat Int 364:172-180

García-Novo F, Ramírez L, Torres A (1975) El sistema de dunas de Doñana. Nat Hisp 5:1-56

Girardi JD, Davis DM (2010) Parabolic dune reactivation and migration at Napeague, NY, USA: insights from aerial and GPR imagery. Geomorphology 114:530-541

Gómez-Ortiz D, Martín-Crespo T, Rodríguez I, Sánchez MJ, Montoya I (2009) The internal structure of modern barchan dunes of the Ebro River Delta (Spain) from ground penetrating radar. J Appl Geophys 68:159-170

González Taboada F, Anadón R (2011) Análisis de escenarios de cambio climático en Asturias. Asturias Regional Government, Asturias

González-Villanueva R, Costas S, Duarte H, Pérez-Arlucea M, Alejo I (2011a) Blowout evolution in a coastal dune: using GPR, aerial imagery and core records. J Coast Res Spec Issue 64:278-282

González-Villanueva R, Costas S, Pérez-Arlucea M, Alejo I, Rial F (2011b) Evolución del sector dunar sur del complejo de Corrubedo. Geogaceta 50(2):177-180

Gracia J, del Río L, Alonso C, Benavente J, Anfuso G (2006) Historical evolution and present state of the coastal dune systems in the Atlantic coast of Cádiz (SW Spain): paleoclimatic and environmental implication. J Coast Res Spec Issue 48:55-63

Gujar AR, Ganesan P, Iyer SD, Gaonkar SS, Ambre NV, Loveson VJ, Mislankar PG (2011) Influence of morphodynamic variability over seasonal beach sediments and its probable effect on coastal development. Ocean Coast Manag 54(7):514-523

Harari Z (1996) Ground-penetrating radar (GPR) for imaging stratigraphic features and groundwater in sand dunes. J Appl Geophys 36:4352

Havholm KG, Ames DV, Whittecar GR, Wenell BA, Riggs SR, Jol HM, Beger GW, Holmes MA (2004) Stratigraphy of back-barrier coastal dunes, northern North Carolina and southern Virginia. J CoastRes 20:980-999

Hesp PA (1984) Foredune formation in southeast Australia. In: Coastal geomorphology in Australia. Academic Press, Sydney, pp 69-97

Hesp PA (1999) The beach backshore and beyond. In: Short AD (ed) Handbook of beach and shoreface morphodynamics. Wiley, New York, pp 145-170
Hesp PA (2002) Foredunes and blowouts: initiation, geomorphology and dynamics. Geomorphology 48:245-268

Hesp PA, Short AD (1999) Barrier morphodynamics. In: Short AD (ed) Handbook of beach and shoreface morphodynamics. Wiley, New York, pp 307-333

Hoyos M (1989) La Cornisa Cantábrica. In: Pérez-González A, Cabra P, Martín-Serrano Á (eds) Mapa del Cuaternario de España. ITGE, Madrid, pp 105-118

Iglesias G, Carballo R (2010) Offshore and inshore wave energy assessment: Asturias (N Spain). Energy 35:1964-1972

Jol HM (ed) (2009) Ground penetrating radar: theory and applications. Elsevier, Amsterdam

Kim D, Grant WE, Cairns DM, Bartholdy J (2013) Effects of the North Atlantic Oscillation and wind waves on salt marsh dynamics in the Danish Wadden Sea: a quantitative model as proof of concept. GeoMar Lett 33:253-261

Łabuz TA (2005) Present-day dune environment dynamics on the coast of the Swina Gate Sandbar (Polish West coast). Estuar Coast Shelf Sci 62:507-520

Leatherman SP (1987) Coastal geomorphological applications of ground penetrating radar. J Coast Res 3:397-399

Lee Y, Gouramanis C, Switzer AD, Bristow CS, Soria JLA, Pham DT, Lam DD, Que HD (2013) Ground penetrating radar (GPR) survey of formerly mined coastal sand in central Vietnam: a rapid, non-invasive method for investigating the extent and impact of mined areas. $\mathrm{J}$ Geol Earth Sci 1:11-19

Leorri E, Cearreta A, Milne G (2012) Field observations and modelling of Holocene sea-level changes in the southern Bay of Biscay: implication for understanding current rates of relative sea-level change and vertical land motion along the Atlantic coast of SW Europe. Quat Sci Rev 42:59-73

Martínez Cortizas A, Costa Casais M (1997) Indicios de variaciones del nivel del mar en la ría de Vigo durante los últimos 3000 años. Gallaecia 16:23-47

Martínez Graña A, Goy JL, Zazo C (2000) Actividad tectónica en el Noroeste Peninsular, en base a los registros de los depósitos costeros de los últimos 130.000 años (rías Arosa-Pontevedra, Galicia). Geotemas 1(4):263-266

Mary G (1983) Evolución del margen costero de la Cordillera Cantábrica de Asturias desde el Mioceno. Trab Geol 13:3-35

Mary G (1992) La evolución del litoral cantábrico durante el Holoceno. In: Cearreta A, Ugarte FM (eds) Proc The Late Quaternary in the Western Pyrenean Region. Bilbao, pp 161-169

Moura D, Veiga-Pires C, Albardeiro L, Boski T, Rodrigues AL, Tareco H (2007) Holocene sea level fluctuations and coastal evolution in the central Algarve (southern Portugal). Mar Geol 237:127-142

Neal A (2004) Ground-penetrating radar and its use in sedimentology: principles, problems and progress. Earth Sci Rev 66(3-4):261-330

NGIA (2014) Sailing Direction (Enroute) West Coast of Europe and Northwest Africa, 15th edn. National Geospatial-Intelligence Agency, 143. http://msi.nga.mil/MSISiteContent/StaticFiles/NAV PUBS/SD/Pub143/Pub143bk.pdf

Nielsen L, Møller I, Nielsen LH, Johannessen PN, Pejrup M, Andersen T, Korshøj JS (2009) Integrating ground-penetrating radar and borehole data from a Wadden Sea barrier island. J Appl Geophys 68(1): $47-59$

Psuty NP (1989) An application of science to the management of coastal sand dunes along the Atlantic coast of the USA. In: Gimingham $\mathrm{CH}$, Ritchie W, Willetts BB, Willis AJ (eds) Coastal sand dunes. Proc R Soc Edinb 96B: 289-307

Psuty NP (2004) The coastal foredune: a morphological basis for regional coastal dune development. In: Martínez ML, Psuty NP (eds) Coastal dunes. Ecology and conservation. Springer, Berlin, pp 11-27

Pye K, Tsoar H (1990) Aeolian sand and sand dunes. Unwin Hyman, London 
Pye K, Saye S, Blott S (2007) Sand dune processes and management. Part 2: Sand dune processes and morphology. R\&D Technical Report FD1302/TR. www.defra.gov.uk/environ/fcd

Ramos R, Freitas MC, Andrade C, Bristow C, Costas S, Grangeia C, Hermozilha H, Senos Matias MJ (2010) Sedimentary structure of the Nazaré coastal dunes (Portugal). In: Ground Penetrating Radar (GPR). Proc 13th Int Conf Ground Penetrating Radar. IEEE Xplore, Lecce, Italy, pp 973-978

Ramos R, Freitas MC, Bristow C, Andrade C, Hermozilha H, Grangeia C, Senos Matias MJ (2011) Sedimentary architecture of the Santo André transverse dunes (Portugal) interpreted from ground-penetrating radar. J Coast Res Spec Issue 64:303-307

Rasilla D, García Codrón JC, Hernández Gimena A (2004) Las mareas atmosféricas en la costa norte de la península Ibérica. In: García Codrón JC, Diego Liaño C, Fernández de Arroyábade Hernáez P, Garmendia Pedraja C, Rasilla Álvarez D (eds) Proc El Clima entre el Mar y la Montaña, Serie A, no 4. Asociación Española de Climatología and University of Cantabria, Santander, pp 135-144

Rodríguez Santalla I, Sánchez García MJ, Montoya Montes I, Gómez Ortiz D, Martín Crespo T, Serra Raventos J (2009) Internal structure of the aeolian sand dunes of El Fangar spit, Ebro Delta (Tarragona, Spain). Geomorphology 104:238-252

Rodríguez-Asensio JA, Flor G (1979) Estudio del yacimiento prehistórico de Bañugues y su medio de depósito (Gozón, Asturias). Zephyrus 29:161-178

Rubin DM (1987) Cross-bedding, bedforms, and paleocurrents. Concepts in sedimentology and paleontology, vol 1. SEPM, Tulsa

Ruz MH, Allard M (1995) Sedimentary structures of cold-climate coastal dunes, Eastern Hudson Bay, Canada. Sedimentology 42:725-734
Short AD (2006) Australian beach systems - nature and distribution. J Coast Res 22:11-27

Short AD, Jackson DWT (2013) Beach morphodynamics. In: Shroder JF (ed) Treatise on geomorphology. Elsevier, Amsterdam, pp 106-129

Suárez Ruiz I, Sánchez de la Torre L (1983) Evolución sedimentaria del sistema playa-duna de Xagó (Asturias). Trab Geol 13:113-128

Tanner WF (1995) Origin of beach ridges and swales. Mar Geol 129:149161

Truman CC, Perkins HF, Asmussen LE, Allison HD (1988) Some applications of ground-penetrating radar in the southern coastal plains regions of Georgia. The Georgia Agricultural Experiment Stations, College of Agriculture, University of Georgia, no 27

Ulriksen CPF (1982) Application of impulse radar to civil engineering. $\mathrm{PhD}$ Thesis, Lund University of Technology, and Geophysical Survey Systems Inc, Hudson, NH

Vallejo I (2007) Caracterización geomorfológica y análisis de la evolución reciente del sistema de dunas activas de P.N. de Doñana (1956-2011). PhD Thesis, University of Sevilla

Van Dam RL (2012) Landform characterization using geophysics: recent advances, applications, and emerging tools. Geomorphology 137: $57-73$

Van Dam RL, Nichol SL, Augustinus PC, Parnell KE, Hosking PL, McLean RF (2003) GPR stratigraphy of a large active dune on Parengarenga Sandspit, New Zealand. Lead Edge 22(9):865-881

Van Heteren S, FitzGerald DM, McKinlay PA, Buynevich IV (1998) Radar facies of paraglacial barrier systems: coastal New England, USA. Sedimentology 45:181-200 